\title{
The Impact of National Office Governance on Audit Quality
}

\author{
Jade Huayu Chen * \\ Dhaliwal-Reidy School of Accountancy \\ University of Arizona \\ chenhuayu@email.arizona.edu \\ Preeti Choudhary \\ Dhaliwal-Reidy School of Accountancy \\ University of Arizona \\ choudharyp@email.arizona.edu
}

October 2020

We appreciate helpful comments and discussions from Nicholas Hallman and participants at the Center of Audit Quality Research Advisory Board research feedback session. We thank the Dhaliwal-Reidy School of Accountancy and the Eller College of Management at The University of Arizona for funding that makes this study possible.

* Corresponding author. 


\title{
The Impact of National Office Governance on Audit Quality
}

\begin{abstract}
We examine the impact of internal audit firm governance on audit quality through national office involvement with local offices. We proxy for national office governance using two measures of geographical proximity, distance and the introduction of frequent, direct airline routes between a practice office and the national office of the firm, where the latter introduces exogenous variation. We predict and find closer proximity strengthens national office governance through more monitoring and knowledge transfer, resulting in better audit quality, captured by lower propensity of restatements. Cross-sectional analyses confirm that the relation varies with national office's sensitivity to costs. Finally, we find that smaller audit firms benefit less from national office governance, consistent with theory that suggests smaller partnership structures have less moral hazard costs and less knowledge transfer benefits from national office governance. Collectively, our results help to explain one avenue that develops audit quality among auditors.
\end{abstract}

Keywords: audit office, audit quality, organizational structure, geographical proximity.

JEL classifications: M41, M42, D20.

Data Availability: All data used in the study is publicly available. 


\section{INTRODUCTION}

In this study, we examine the impact of national office governance of local audit offices on audit quality. Audit firms are generally organized as partnerships, made up of local city-based offices that pool resources. While each local office has its own independent operating characteristics, they also connect with each other as a "unified corporate identity" (Seavey, Imhof, and Westfall 2018), sharing both profits and reputation. As the quality of audits is not easily observable, and heterogeneity in resources available in local offices exists, the decentralized structure of audit firms introduces problems related to moral hazard and resource constraints to local audit offices. We investigate whether national office governance combats these concerns.

Because auditing is an important pillar of effective and efficient capital markets, many market participants have focused on understanding and evaluating high audit quality defined as a "greater assurance of high financial reporting quality" (DeFond and Zhang 2014). For example, stock market investors use various auditor characteristics such as audit firm brand name as signals of audit quality and exhibit greater responsiveness to earnings announcements (i.e., higher earnings response coefficients) for companies audited by auditors they perceived as higher quality (Teoh and Wong 1993; Balsam, Krishnan, and Yang 2003; Gipper, Leuz, and Maffett 2019). Regulators across the world have also launched audit quality indicator projects to assess and communicate the drivers of audit quality in response to the demand from the capital markets (Maijoor and Vanstraelen 2012). In the U.S., recent regulatory changes have focused on assessing and passing a variety of new rules and procedures, aiming to improve audit quality and communicate audit quality to investors more efficiently (e.g., disclosure of engagement partner names, PCAOB Rule 3211; communication of critical audit matters, PCAOB AS3101). These practices underscore the 
importance of providing high-quality assurance and the need to understand the various ways that high-quality assurance is achieved.

Accordingly, extant auditing literature identifies several ways that audit quality is developed or achieved. For example, prior research establishes that larger audit firms often have higher audit quality (e.g., DeAngelo 1981; Teoh and Wong 1993), and expands this analysis to various characteristics of practice offices within an audit firm, such as Big N office size (e.g., Francis and Yu 2009; Choi, Kim, Qiu, and Zang 2012; Francis, Michas, and Yu 2013), industry specialization (e.g., Francis, Reichelt, and Wang 2005; Reichelt and Wang 2010), and independence (e.g., Reynolds and Francis 2000). In this study, we extend the literature by evaluating a less explored dimension that contributes to audit quality of a local office, national office governance.

National offices in large audit firms fulfill a critical role of internal monitoring to combat moral hazard, and knowledge transfer to address resource constraints (Bedard, Johnstone, and Smith 2010). To better understand how national office governance can improve office-level audit quality, we performed several semi-structured interviews of local and national audit partners from various audit firms. Responses indicate national offices organize and execute internal inspections that review the practice of each partner and engagement periodically, not only to provide performance evaluations, but also to identify audit deficiencies to minimize audit risk. To further ensure high-quality audits, national offices commit to providing resource and expertise on issues related to both auditing and accounting that individual engagement teams can access as needed. National offices also develop training programs and customizable audit processes and procedures to support high quality audits (EY 2019; PwC 2019). 
To evaluate the level of national office governance, we build upon recent literature on geographical proximity that finds proximity reduces information asymmetry between economic agents by facilitating knowledge sharing and monitoring through lowering costs of communication (e.g., Coval and Moskowitz 2001; Malloy 2005; Choi et al. 2012; Kedia and Rajgopal 2011). Specifically, national office governance requires timely and reliable information about local practices. Through interaction with local offices, a national office can better learn what their needs are, generating a feedback loop, which in turn allows the national office to better fulfill the needs of the local offices to further improve audit quality. Consistent with proximity improving efficiency of information transfer, we expect that national office governance is more effective when the source of monitoring and knowledge transfer (i.e., national office) is in closer proximity to the target (i.e., local offices).

We analyze a broad sample of data with 32,987 client-year observations between 2000-2017 of Big 4 audit clients to examine the relation between national office governance and audit quality. We use two geographical proximity proxies to measure national office governance. First, we calculate the total distance between the local offices and the national office of the firm using the geographic coordinates for each city that has an audit office. However, because audit office locations change infrequently, this measure can be subject to alternative explanations. Hence, we exploit a second measure based on the introduction of direct flight routes that reduces travel time between two locations (e.g., Giroud 2013; Bernstein, Giroud, and Townsend 2016). If national office governance matters, a reduction in travel time should translate into better local office performance through more efficient monitoring and knowledge transfer from national office. Using this measure creates a staggered difference-in-differences research design, enhancing causal inferences by exploiting an exogenous source of variation. Consistent with prior studies on audit quality (e.g., Dechow, Ge, Larson, and Sloan 2011; Francis, Michas, and Yu 2013; Rajgopal, 
Srinivasan, and Zheng Forthcoming), we measure audit quality via the propensity of restatements, using all restatements and non-reliance restatements with 8-K Item 4.02 only.

We include a set of proximity-based controls prior literature has explored to better isolate the impact from national office governance. Specifically, we control for the proximity of the local audit office to the closest SEC regional office, which proxies for monitoring by the regulator (Kedia and Rajgopal 2011), and the proximity of the local audit office to the closest large audit office of the same audit firm to proxy for monitoring, knowledge transfer, and resource sharing among the practice offices (Beck, Gunn, and Hallman 2019). The latter is most closely related to our study as it examines proximity within an audit firm, but assumes that most of the monitoring, knowledge transfer, and resource sharing happen at a regional, not national level. We also control for the proximity of a practice office to its clients, as this has been shown to affect auditor's ability to communicate and monitor the clients (Choi et al. 2012). Finally, we include a comprehensive set of client, auditor, and city characteristics that have been shown to affect audit quality (e.g., Dechow et al. 2011; Francis et al. 2013).

After controlling for a variety of factors, we find evidence that national office governance, as captured using either distance or the introduction of frequent direct airline routes between a local office and its national office, is negatively associated with the propensity of financial restatements of the local office. This evidence is consistent with the view that geographical proximity provides national offices with greater opportunity to monitor and share knowledge with local offices, leading to higher audit quality. Crosssectional analyses confirm the relation between national office proximity and audit quality is more (less) pronounced in the presence of sensitivities to costs faced by national office. Specifically, we find that the impact of national office proximity on restatement likelihood is 
exacerbated in the presence of time constraints faced by the national office and tempered in the presence of the need to address regulator-identified audit deficiencies.

We further explore the channels through which national office governance affects audit quality. We find the impact of national office governance is attenuated when an alternative monitoring mechanism, the Public Company Accounting Oversight Board (PCAOB), is introduced to combat moral hazard, highlighting that monitoring is one channel of national office governance that affects audit quality. We also find the impact of national office governance is greater (less) when opportunities of knowledge transfer from regional offices are not as accessible (not as needed), highlighting the knowledge transfer channel through which national office governance matters for audit quality.

As a falsification test, we find that small audit firms (i.e., tier 2 audit firms) exhibit less benefit from national office governance on audit quality, consistent with theory that predicts smaller audit firms have less moral hazard problems and benefit less from national office solving resource constraint issues. Moreover, our results are robust to controlling for variation in MSA-year following Bertrand and Mullainathan (2003) and Giroud (2013), which corroborates our assumption that the introduction of frequent direct airline routes is exogenous in our setting. Finally, our findings are robust to using airline ticket price as an alternative proxy for the costs of national office governance.

Due to limited requirements that currently exist in the U.S. for audit firms to publicly disclose information about their governance, there has been little empirical work regarding the organizational structure within audit firms and how internal monitoring affects auditor behavior and performance. Our study provides some of the first empirical evidence on the impact of governance practices within audit firms by recognizing the importance of national office governance and the role of geographical proximity in facilitating the governance. In 
this regard, this paper is informative to document whether and how audit firms govern and oversee the business activities conducted at the practice office level, and whether the internal monitoring mechanisms have impact. It informs the policymakers who are constantly evaluating the necessary level of transparency on audit firms' internal governance practices (e.g., IOSCO 2009). Furthermore, our findings bring insights to audit firms in making decisions concerning the organizational structure and the optimal extent of geographic expansion. While the study focuses on the network of audit firms within the U.S., our findings may be of particular interest for researchers examining the global network of audit firms.

Further, in viewing national offices as an integral part of audit firms, our study suggests that the interaction between national offices and local offices as a form of firm governance plays a role in audit quality, which has been overlooked in extant audit quality models. Our findings recognize national office governance as an important determinant of audit quality, and present factors that may enhance (attenuate) its impact. In doing so, we respond to DeFond and Zhang's (2014) call to explore dimensions of auditor competency and their role in driving audit quality.

Finally, our study contributes to a growing literature that documents geographical proximity affects monitoring and information transfer in the context of auditing. Much of the previous work has focused on the proximity between the auditor and external parties such as clients and regulators (Kedia and Rajgopal 2011; Choi et al. 2012; Hanes 2013; Brooks and Yu 2013; Thammasiri 2014; Jensen, Kim, and Yi 2015). More recently, some of this literature extends the proximity analysis to a setting within audit firms and argues that the proximity between practice offices impacts knowledge and resource sharing, and therefore audit quality (Seavey et al. 2018; Beck et al. 2019). Our paper extends this literature not only by evaluating the role of geographical proximity in audit firms' governance of local practices, 
but also by pointing to a useful alternative measure to capture geographical proximity, the availability of direct flight routes.

\section{RELATED LITERATURE AND HYPOTHESIS DEVELOPMENT}

Audit firms have a decentralized organizational structure that operates through local, city-based offices (Seavey et al. 2018; Beck et al. 2019). The local offices operate with considerable autonomy with respect to client contracting and the delivery of assurance services (Wallman 1996; Francis, Maydew, and Sparks 1999; Reynolds and Francis 2000; Ferguson, Francis, and Stokes 2003; Reichelt and Wang 2010). This decentralized structure increases the proximity between each practice office and their clients, allowing the local office to obtain information about local market conditions as well as client-specific knowledge. Decentralization also helps auditors plan audits and evaluate audit risks more effectively, in turn, improving audit quality (Carcello, Hermanson, and McGrath 1992; Christie, Joye, and Watts 2003; Myers, Myers, and Omer 2003; Knechel, Niemi, and Zerni 2013). Despite the benefits, at least two challenges arise in providing high-quality audits from the audit firm's decentralized structure: moral hazard and resource constraints. Below we describe each in more detail. To gain a better understanding of the governance role played by national offices in addressing these issues, we conduct semi-structured interviews with partners from each of the big 4 firms, including both national and local office partners. Based on these conversations, we further elaborate on how a national office of a firm attempts to address these issues.

\section{Moral Hazard and National Office Monitoring}

The first challenge that arises from a decentralized organizational structure is moral hazard. Audits are credence goods where the users of financial statements do not possess perfect information about audit quality (Causholli and Knechel 2012). As a result, clients infer audit quality information from auditor reputation. One of the most salient indicators of 
auditor reputation is the audit firm's brand name, where capital markets typically expect the same quality across different entities under the same brand name (Maijoor and Vanstraelen 2012). In the case of audit failure, the large downside costs from impaired reputation and increased scrutiny from investors and regulators are mostly borne by the audit firm as a whole. Extensive literature in audit failure has documented that one incidence of audit failure can cause significant consequences to the whole audit firm, such as a higher rate of client turnover and reduced audit market share (e.g., Chaney and Philipich 2002; Weber et al. 2008). Meanwhile, partners typically buy into the partnership and share in the collective profits of the overall audit firm (Levin and Tadelis 2005). Hence, the local offices share profits and reputation collectively.

As noted by Huddart and Liang (2005), when ownership and control are diffused among the intra-corporate network where the net output is shared in the collective partnership, it introduces a moral hazard problem. Limited knowledge of other professionals' actions further increases the incentives for the professionals to free ride or shirk (Holmstrom 1982). At the same time, contracting, a typical way to solve such moral hazard problems, becomes implausible because of the difficulty to observe audit quality on the engagement level that could be attributed to an individual's work.

To combat incentives to shirk from moral hazard, large audit firms have allocated considerable resources to their national offices to perform several monitoring tasks (Bedard et al. 2010). For instance, national offices inspect individual engagements both pre and post the audit opinion to evaluate the effectiveness of local engagement teams. From frequent inspections, national offices identify audit deficiencies across several audits to minimize audit risk through analyses such as root cause. In addition, national offices constantly monitor compliance with internal and external standards of independence, risk assessment, audit 
standards, and ethics. These monitoring activities generate signals about the quality of local audit professionals' work, combating incentives to shirk.

\section{Resource Constraints and National Office Knowledge Transfer}

The second challenge that arises from a decentralized structure is the lack of full and complete resources being accessible to each local office. The issue stems from at least two sources. First, the supply of human capital varies on the basis of innate abilities available in the local markets. Secondly, there is variation in knowledge among the local offices who may develop expertise or best practices in different areas but be unaware of the expertise and best practices that may exist in other local offices whom they have little contact with. In the absence of information sharing and knowledge transfer, this heterogeneity in skills and expertise will translate into heterogeneous audit quality across local offices within an audit firm. However, in the aftermath of the high-profile corporate failures and the changes in the professional auditing environment in the past two decades, we observe that audit firms face increased pressure to improve internal consistency through professional policies and procedures that enhance the internal governance and ensure consistent high quality.

Discussions with audit professionals indicate that large firms maintain internal quality control and provide resources to local offices with varying needs via national offices. National offices serve an essential role in coordinating resources and developing centralized knowledge to alleviate gaps in expertise across local offices in several ways. First, national offices provide expertise on technical issues related to both auditing and accounting; individual engagement teams access consultation as needed (Bedard et al. 2010). Second, national offices develop training programs to remediate audit deficiencies and generate best practices to address changes in regulatory auditing and accounting standards as well as changes in market conditions/client needs (EY 2019; PwC 2019). National offices also 
develop customizable audit processes and procedures, as well as the reference literature that local offices can consult in the course of conducting an audit. Third, national offices contribute to the development of human resource policies and procedures that are intended to aid in the evaluation, compensation, and retention of partners and staff in local practices, which can have direct impact on their incentives to provide quality audits. For example, the national office can provide instructions on the appraisal and compensation policies regarding the performance evaluation and internal and/or external inspection findings. All of these activities are enhanced by observing the deficiencies in skills among local practices such that national offices can better facilitate knowledge transfer in addressing these issues.

In sum, white papers issued by audit firms and our discussions with practitioners suggested that national office governance serves an important role under the decentralized organizational structure of audit firms through monitoring and knowledge transfer. The effectiveness of the two mechanisms depends largely on opportunities for national offices to acquire timely and reliable information about the local offices. This enables national offices to both learn what the needs are of the local practices and develop an appropriate strategic direction.

\section{Proximity and Audit Quality}

The proximity of national offices to the local offices can enhance both monitoring and knowledge transfer. Extant literature in geographical proximity suggests that closer proximity between principles and agents results in reduced monitoring costs and increased frequency and length of monitoring, which, in turn, is associated with improved outcomes such as performance, productivity, and quality (e.g., Petersen and Rajan 2002; Malloy 2005; John, Knyazeva, and Knyazeva 2011; Kedia and Rajgopal 2011; Chhaochharia, Kumar, and Niessen-Ruenzi 2012). For example, Ayers, Ramalingegowda, and Yeung (2011) show that 
local institutional shareholder monitoring improves corporate governance such that managers are less likely to misreport in the presence of moral hazard. Degryse and Ongena (2005) find that companies receive lower interest rates when located closer to their lending banks, and they attribute this to lower monitoring costs. More similar to our setting, Giroud (2013) shows that a plant that is in closer proximity to its company headquarters within a decentralized company is more likely to receive investment from the headquarters and have higher plant-level productivity due to lower information asymmetry and monitoring costs. In line with these arguments, we expect that national office proximity to local offices lowers its monitoring costs, increasing its ability to combat moral hazard incentives presented in local offices.

Geographical proximity also facilitates knowledge transfer by increasing information exchange between economic agents (e.g., Audretsch and Feldman 1996; Audretsch and Stephan 1996; Bernstein et al. 2016). Seavey et al. (2018) suggest that tacit knowledge sharing on matters related to engagements depends largely on opportunities for partners to interact with each other. In our setting, national office proximity likely increases both formal and informal interactions between national office professionals and local auditors, which allows national offices to better understand the operation of local offices and to improve the efficiency and effectiveness of knowledge transfer in combating resource constraints. It also provides national offices with a better understanding of the needs of the local offices to improve future consultations. Taken together, we expect geographical proximity strengthens national office governance, as both monitoring and knowledge transfer will improve when national office can frequently communicate with local offices.

Alternatively, there are several possible explanations that work against us observing an association between national office proximity and audit quality. First, if the monitoring function is sufficiently distributed among individual practices (such as regional offices), then 
the incremental effect of national office governance may not matter much. For example, Beck et al. (2019) find that connections with a close-by large audit office promote monitoring and information transfer. To the extent these channels are effective at addressing moral hazard and resource constraints, the incremental benefit of national office governance may be minimal. Second, it is possible that national offices are able to effectively monitor local offices through remote communication (e.g., creating databases to track data, development of clear policies and practices, etc.). In this case, geographical proximity may not matter much as technological advances may reduce the monitoring costs substantially. Third, it is possible that the time spent by the local professionals on national office interactions detracts them from spending more time on client assurance or training in a more effective way, such that the net benefit of face-to-face communication is matched by the cost. Finally, as a complete assessment of audit quality is nearly impossible to observe, it is unclear if national office governance will affect an observable outcome of audit quality. Given these arguments, we state our hypothesis (in the null form) as:

H1: National office proximity is unrelated to the audit quality provided by a local office.

\section{RESEARCH DESIGN AND DESCRIPTIVE STATISTICS}

\section{Research Design}

To test our hypothesis, we examine the effect of proximity between the local and national offices on audit quality of local offices by estimating the following OLS model: ${ }^{1}$

$$
\begin{aligned}
\text { RESTATE }= & \beta_{0}+\beta_{1} \text { PROXIMITY }+\sum \beta_{i} \text { Other Proximity Controls } \\
& +\sum \beta_{j} \text { Client Controls }+\sum \beta_{k} \text { Auditor Controls }+\sum \beta_{l} \text { City Controls } \\
& + \text { Fixed Effects (Industry, Year, Audit firm) }+\varepsilon
\end{aligned}
$$

Consistent with Francis and Yu (2009) and Francis et al. (2013), we conduct our analysis at the engagement level (i.e., a client-year is our unit of observation) rather than aggregating

\footnotetext{
${ }^{1}$ We estimate OLS to ease with economic interpretations, however, our results are robust to a probit specification (untabulated).
} 
office level because we believe engagement level factors are important to control for when using restatements as a measure of audit quality. RESTATE is one of the two measures that capture the quality of audits performed by an audit office for a client firm in year $t$. The first is $R E S T A T E \_A L L$, which equals one if a firm subsequently issues any restatement related to its current-year financial statements (including both non-reliance restatements issued under Item 4.02 in $8-\mathrm{K}$ filings and other restatements), and zero otherwise. We consider both "big and little R" restatements as Choudhary, Merkley, and Schipper (2019) highlight little R's implications for financial reporting reliability. The second measure is $R E S T A T E \_B I G R$, which equals one if a firm subsequently issues a non-reliance restatement under Item 4.02 in 8-K filings related to its current-year financial statements, and zero otherwise. A non-reliance restatement suggests that the information in the original financial reports can no longer be relied upon, and it offers "strong evidence of poor audit quality" (DeFond and Zhang 2014; Rajgopal et al. forthcoming). An increase in the propensity of subsequent restatements indicates lower audit quality.

PROXIMITY is one of the two proxies we use to measure national office proximity to local offices. First, we use PROXIMITY_TO_NATIONAL, which is the total distance (in thousands of miles) between the local and the national offices of the firm multiplied by negative one; higher values correspond to closer proximity. As suggested by prior literature (e.g., Malloy 2005), when the national office is near a local audit office, the national office should have lower monitoring costs to address moral hazard and lower knowledge transfer costs to address resource constraints.

Because PROXIMITY_TO_NATIONAL exhibits little variation across time or across audit firms, ${ }^{2}$ we enhance causal inferences by exploiting the introduction of direct airline

\footnotetext{
${ }^{2}$ All the national offices for the big 4 audit firms are in the New York area during our sample period.
} 
routes between the national and local audit office, which introduces exogenous variation to the costs of national office governance (Giroud 2013; Bernstein et al. 2016). We argue such changes in flight patterns should be exogenous to audit quality as flight pattern decisions are likely to be driven by airline competition and demand. ${ }^{3}$ Accordingly, our second test variable is DIRECT, measured as an indicator that equals one when a direct airline route between the national office and the local office with at least 100 flights per year has been introduced by time $t$, and zero otherwise. ${ }^{4}$ The national office partners we interviewed with emphasized the importance of in-person internal inspections and communication in improving audit quality. Thus, we believe a frequent direct airline route facilitates monitoring and knowledge transfer between the local office and national office by reducing the travel time necessary, resulting in more frequent interactions.

Using DIRECT as a measure of national office governance results in a staggered difference-in-differences research design. Restatement propensity is estimated for the clientyears whose auditors (measured at the office level) have a direct flight route to the national office, compared with client-years whose auditors do not have a direct flight route to the national office. Due to the staggered nature of the introduction of new airline routes, this implies an office remains in the control group until it is treated (which, for some offices, maybe never).

The main coefficient of interest in equation (1) is $\beta_{1}$, which measures the effect of the national office governance on audit quality. A negative $\beta_{1}$ represents that, on average, the

\footnotetext{
${ }^{3}$ However, we relax this assumption when we provide additional evidence that our results hold on the direct flight measure when adding controls for MSA-year following Bertrand and Mullainathan (2003) and Giroud (2013) in Table 8.

${ }^{4}$ We use a direct airline route with at least 100 flights per year as we believe a high frequency direct flight route plausibly provides convenient of travel to national office professionals. In untabulated analyses, we also consider four alternative measures of DIRECT. Alternative one is a continuous variable that equals the frequency of direct flights between the national office and the local office during time t. Alternative two is an indicator that equals one when a direct airline route between the national office and the local office with at least one flight per year has been introduced by time t, and zero otherwise. Alternative three (four) is an indicator that equals one when a direct airline route between the national office and the local office with at least six (12) months has more than nine flights per month (sample median) has been introduced by time $t$, and zero otherwise. Results are qualitatively similar.
} 
audit quality provided by local offices improves with the increase of national office governance. We include a set of proximity controls that have been found to be associated with audit quality due to regulatory monitoring (Kedia and Rajgopal 2011; DeFond, Francis, and Hallman 2018), information transfer between the auditor and the client (Choi et al. 2012), and intra-corporate connections between large and small audit offices (Beck et al. 2019). Accordingly, we control for the proximity of the local office to the closest SEC regional office, PROXIMITY_TO_SEC, to the client's headquarters, PROXIMITY_TO_CLIENT, as well as to the closest large office of the same audit firm, PROXIMITY_TO_LARGE. The precise definitions appear in Appendix A for all variables.

We also control for a variety of client characteristics that prior research shows are associated with financial reporting quality, and thus restatements: SIZE_CLIENT, CASH_FLOWS, LOSS,DEBT, RSST_ACC,CHG_REC,CHG_INV,CHG_CASH_SALE, CHG_EARN, CHG_EMP, ISSUE, OP_LEASES, BTM, ABNORMAL_RET, TENURE, AUDITOR_CHANGE, and GC (e.g., Dechow et al. 2011; Francis et al. 2013). In addition, we control for auditor characteristics prior research has shown to affect audit quality (e.g., Reynolds and Francis 2000; Balsam et al. 2003; Hennes, Leone, and Miller 2008; Kedia and Rajgopal 2011), including SIZE_AUDITOR, AUDIT, NON_AUDIT, INFLUENCE, NATIONAL_LEADER, and CITY_LEADER.

Beck, Francis, and Gunn (2018) find that city-specific labor characteristics such as changes in demographics and general business development can affect the accounting expertise an audit office possesses and in turn, the quality of audits it provides. As these may also be correlated with flight patterns, we include MSA-level GDP per capita, GDPPC, to control for the wealth of an area where auditors live, and population data, POPULATION, to 
control for local economic development. ${ }^{5}$ We obtain the data from the Bureau of Economic Analysis.

Finally, we include year fixed effects to control for broad macro-economic changes over time, client industry fixed effects (based on two-digits SIC codes), and audit firm fixed effects to account for unobserved heterogeneity across client industries and audit firms. All continuous variables are winsorized at the 1 percent and 99 percent level to mitigate the influence of outliers, and we cluster standard errors at audit office by year level as this is the level at which our variable of interest is calculated (Petersen 2009).

\section{Sample Construction}

Table 1 summarizes our sample selection. We begin with 63,012 U.S. client-year observations audited by U.S. Big 4 firms that have matched data on Compustat and Audit Analytics from 2000 through $2017 .{ }^{6}$ We limit our sample to clients of the Big 4 audit firms so that we can separate national office governance from a Big 4 effect (e.g., Balsam et al. 2003; Krishnan 2003). More specifically, these firms are of similar size/structure (e.g., Teoh and Wong 1993); they operate the largest networks of offices across the United States. We extract data on the locations (city and states) of auditors' practice offices from the Audit Analytics database and the locations of client firms' headquarters from Compustat and retrieve the geographic coordinates for each location. Because Audit Analytics does not provide historical national office locations, we manually collect this information from the Accounting Today Top 100 Firms that is published every year since 1995 . We verify that the national office locations of the Big 4 accounting firms have not changed over our sample period. We

\footnotetext{
${ }^{5}$ In sensitivity tests, we find our results remain robust to including MSA by year controls (see details in section IV).

${ }^{6}$ Post-SOX, firms are required to disclose a non-reliance restatement under Item 4.02 in 8-K filings when their previously issued financial statements can no longer be rely upon. Therefore, the announcement dates for non-reliance restatements are all in or after 2014. However, the restated period for non-reliance restatements can go back as early as 1989 in the database. Thus, we include the period from 2000 when constructing our two RESTATE measures. We end our sample period in 2017 to allow sufficient time for the subsequent restatements to be announced (Francis et al. 2013).
} 
eliminate 1,052 client observations due to missing necessary geographic information.

Restatements are identified using the Audit Analytics Restatements database.

Next, we merge our sample with the data on airline routes from the T-100 Domestic Segment Database provided by the Bureau of Transportation Statistics. This data includes information on all airlines operating flights in the United States. More specifically, for each flight, the data contains the origin and destination cities and airports, flight duration, scheduled departures, performed departures, enplaned passengers, and aircraft type. We use this data to identify direct flights available between two cities as well as the frequency of each direct airline route and merge accordingly with our auditing and financial statement data.

We eliminate 27,941 observations missing required data for client firm controls, 960 observations missing required data for the audit firm and office controls, and 72 observations missing required data for city controls. Our final sample contains 32,987 client-year observations, consisting of 4,406 unique clients and 342 unique audit offices. When using DIRECT to proxy for national office governance, we further eliminate 7,688 firm-year observations, because these observations have local offices located within 200 miles from the national office; for these shorter distances, flight patterns are unlikely to capture the cost of monitoring. ${ }^{7}$ The sample used for the DIRECT analysis contains 25,299 firm-year observations.

\section{Descriptive Statistics}

During our sample period, the Big 4 audit firms had offices in an average of 70 U.S. cities, ranging from a low of 57 cities (Deloitte in 2014) and a high of 85 cities (KPMG in

\footnotetext{
${ }^{7}$ We drop these observations because when using DIRECT as the proximity measure, the local office needs to be sufficient far away from the national office such that air travel is the optimal means of transportation. Although the cutoff on 200 miles reflects what we believe are sensible estimates, we note that our results are robust to alternative distance cutoffs (no cutoff, 100 miles, and 300 miles).
} 
2002). In Figure 1, we marked all practice offices of PwC in the most recent year in our sample (i.e., 2017) to provide a visual depiction of the geographic decentralization of the local offices in a Big 4 firm. Figure 1 shows the audit firm maintains extensive networks of practice offices throughout the country. This decentralized structure increases the proximity between each practice office and their clients (the median distance between an audit office and its client's headquarters is 12 miles, as shown in Table 2, Panel A), allowing the local office to obtain information about local market conditions as well as client-specific knowledge, and reducing travel cost/time to service the clients. However, as practice offices are geographically distributed across the country, the proximity between the local and the national office, which is located in New York, NY (as marked in black in Figure 1), is on average low.

Table 2, Panel A reports descriptive statistics of all variables in our main analyses. Our sample reports that 20 (9) percent of observations issue a restatement, indicated by RESTATE_ALL (a non-reliance restatement under 8-K Item 4.02, indicated by RESTATE_BIGR) related to its current-year financial statements, consistent with prior research that use restatement to proxy for audit quality (e.g., Francis et al. 2013; Cohen, Hoitash, Krishnamoorthy, and Wright 2014; Ashraf, Michas, and Russomanno 2019). The mean (median) value for PROXIMITY_TO_NATIONAL is $-1.05(-0.75)$, indicating that the mean (median) distance from a local office to the national office of the firm is 1,050 (750) miles. Again, this distance confirms the geographically decentralized arrangements of audit firms where the practice offices are mostly far away from their national offices and provides support to our argument that airline routes could be an important determinant of monitoring costs for the national offices. The mean value for DIRECT is 0.32 , indicating that approximately 32 percent of observations have a frequent direct airline route between their 
auditor's practice office and the national office been introduced, which corresponds to 100 treated local-national office pairs.

The average values for PROXIMITY_TO_SEC,PROXIMITY_TO_CLIENT, and PROXIMITY_TO_LARGE are -0.14, -0.12, and -0.19, indicating the average distance to the closest SEC regional office, the client headquarters, and the closest large office within the same audit firm are 140 miles, 120 miles, and 190 miles, respectively, similar to the values reported in Kedia and Rajgopal (2011), Choi et al. (2012), and Beck et al. (2019). We also present descriptive data on our client, auditor, and city control variables. The mean values of our controls are generally consistent with prior literature (Dechow et al. 2011; Francis et al. 2013).

In Table 2, Panel B, we report descriptive statistics across sample observations with and without direct airline routes. We report initial univariate results that clients with direct flights between national and local audit office have lower propensities to restate (i.e., low value for both RESTATE_ALL and RESTATE_BIGR; $\mathrm{p}<0.01)$. Consistent with the notion that PROXIMITY_TO_NATIONAL and DIRECT capture similar constructs, we find that the offices with direct flights are located farther away from the national offices (i.e., a lower value for PROXIMITY_TO_NATIONAL; $\mathrm{p}<0.01)$. We also find that other proximity-based measures, shown by prior research to be associated with audit quality, are lower for the direct versus non-direct samples $(\mathrm{p}<0.01)$, highlighting the need to control for these factors in multivariate analyses. Further, many of the control variables differ between the direct and non-direct samples $(\mathrm{p}<0.10$ or better), providing additional indication warranting multivariate analysis.

\section{RESULTS}

\section{Main Tests of H1: National Office Monitoring and Audit Quality}


Table 3 presents our multivariate results that test $\mathrm{H} 1$ using model (1) on whether the proximity between the local and national offices are associated with audit quality. Consistent with prior research (e.g., Reynolds and Francis 2000; Kinney, Palmrose, Scholz 2004; Li 2009; Dechow et al. 2011), client firm size (SIZE_CLIENT), auditor tenure (TENURE), and the ratio of a specific client's total fees to the aggregated client fees generated by the audit office (INFLUENCE) are negatively related to restatements $(\mathrm{p}<0.05$ or better). Clients with a $L O S S$, higher levels of $D E B T$, higher $B T M$ ratio, higher increase in inventory $\left(C H G \_I N V\right)$, higher increase in operating lease obligations $\left(O P \_L E A S E S\right)$, a new auditor (AUDITOR_CHANGE), and those that pay higher audit fees (AUDIT) are more likely to have restatements (e.g., Skinner and Sloan 2002; Hennes, Leone, and Miller 2008; Dechow et al. 2011).

The coefficient $\beta_{1}$ measures the effect of PROXIMITY_TO_NATIONAL in columns (1) and (2), and the effect of DIRECT in columns (3) and (4). Columns (1) and (3) report RESTATE_ALL as the dependent variable, whereas columns (2) and (4) report RESTATE_BIGR as the dependent variable. After controlling for other factors that are associated with restatements, we find negative and significant coefficients $(\mathrm{p}<0.05$ or better) on both measures of national office proximity, suggesting that there are fewer restatements with closer proximity between the local and national offices. These results are consistent with rejecting $\mathrm{H} 1$ and suggest national office governance having a positive influence on audit quality. The effect is also economically meaningful. For example, the results in columns (3) and (4) indicate that the propensity of all (non-reliance) restatements is lower by 1.5 percentage points when there are frequent direct airline routes, which accounts for 7.5 (16.7) percent decrease when compared to the unconditional mean of restatement propensity. Taken together, the evidence in Table 3 supports the conjecture that the lower national office monitoring costs and knowledge transfer costs improve audit quality. 


\section{Dynamic Effects of the Introduction of Direct Airline Routes}

To enhance causal evidence, we evaluate model (1) using the DIRECT measure of proximity more carefully by further exploiting the dynamic effects of the introduction of direct airline routes in Table 4. Specifically, we replace DIRECT in model (1) with four time series indicators: DIRECT_INTRO_PRIOR is an indicator equals to one if the observation is the year before the frequent, direct airline route is introduced between the local and national audit office, DIRECT_INTRO is an indicator equals to one in the year a frequent, direct airline route is introduced between the local and national audit office, $D I R E C T_{-}$ INTRO_POST is an indicator equals to one in the year after the frequent, direct airline route is introduced between the local and national audit office, and DIRECT_CONT is an indicator equals to one in two or more years after the frequent, direct airline route is introduced between the local and national audit office.

Column (1) and (2) in Table 4 report results when the dependent variable is RESTATE_ALL and RESTATE_BIGR, respectively. If audit quality is affected by national office governance, and the level of governance increases once direct airline routes are introduced, we would not expect there to be an "effect" of the new direct airline route on audit quality before the flight introduction. Accordingly, we find in Table 4, the coefficient on DIRECT_INTRO_PRIOR is insignificant ( $\mathrm{p}>0.10)$ in both columns. In the year when the frequent airline routes are introduced, there may be a negative relation; since it's the first year of increased national office governance, it's unclear if the increased monitoring and knowledge transfer will affect audit quality immediately or with delay. We find a negative and significant coefficient on DIRECT_INTRO in both columns ( $<<.05$ or better). We expect and find a negative and significant coefficient on $D I R E C T_{-} I N T R O_{-} P O S T(\mathrm{p}<0.01)$ in both columns, consistent with lower propensity of restatements when national office governance increases. Finally, we expect the effect of national office governance on audit 
quality to persist when direct flights continue to be available and find that the coefficient on DIRECT_CONT is also negative and significant in both columns ( $\mathrm{p}<0.05$ or better). In sum, the dynamic pattern suggests that the introduction of frequent direct airline routes materializes into increased national office governance and lower likelihood of restatements.

\section{Cross-sectional Analyses}

We perform additional cross-sectional analyses to enhance existing evidence of $\mathrm{H} 1$ and shed further light on circumstances in which the effect of national office governance is more or less sensitive to costs. First, we hypothesize that when the audit firm is dealing with a high-visibility scandal, the national office gets tied up or focused at least in part on resolving the issue, leaving less time available for the national office to be engaged in monitoring and knowledge transfer activities. Due to the increased time constraints faced by the national office, we believe the national office activities would likely be more sensitive to travel time, and consequently, proximity becomes more likely to affect national office governance. To examine this hypothesis, we create an indicator variable, SCANDAL, which equals one in the year of the revelation of a major audit scandal(s) and the two years after. A list of major audit scandals we identify during our sample period appears in Appendix B, along with the audit firm involved and the revelation year. ${ }^{8} S C A N D A L$ varies across audit firms and across time; 36.5 percent of client observations fall in a scandal period, as reported in Table 2 Panel A. We add SCANDAL and an interaction between SCANDAL and each of the two PROXIMITY measures to model (1). We expect a negative coefficient for the interaction term, consistent with the national office's sensitivity to time constraints to increase in the wake of the scandal.

\footnotetext{
${ }^{8}$ We thank Nicholas Hallman and Samantha Ross for helping us generate the list of audit scandals.
} 
Table 5, Panel A reports the results of this test. Similar to our analysis in Table 3, columns (1) and (2) report the impact to RESTATE_ALL and RESTATE_BIGR, respectively, with PROXIMITY_TO_NATIONAL and PROXIMITY_TO_NATIONAL*SCANDAL.We replace PROXIMITY_TO_NATIONAL with DIRECT in columns (3) and (4). We continue to find a negative coefficient on PROXIMITY_TO_NATIONAL in columns (1) and (2) $(\mathrm{p}<0.01)$ and on DIRECT in column (4) ( $\mathrm{p}<0.10)$, consistent with our findings in Table 3 and the rejection of H1. More importantly, consistent with our expectation of increased time sensitivity during an audit firm scandal, we find a negative coefficient on the interaction between SCANDAL and PROXIMITY_TO_NATIONAL or DIRECT in all four columns (p $<0.10$ or better with the exception of column 2 where $\mathrm{p}=0.10)$.

Second, we hypothesize that national office governance will be less sensitive to costs when the audit firm must address audit deficiencies highlighted by regulators. In these instances, we expect national office governance to be less sensitive to proximity because they would be more focused on addressing the concerns or issues raised by regulators. ${ }^{9}$ To evaluate this possibility, we introduce a new proxy, PARTI_INCREASE, that captures the change in audit deficiency rates, which varies across both audit firms and time. PARTI_INCREASE equals one if the ratio of total Part I Findings to total engagements reviewed by the Public Company Accounting Oversight Board (PCAOB) increases by over 10 percent as compared with the prior year, and zero otherwise. ${ }^{10}$ The mean value of PARTI_INCREASE shows that 17.9 percent of clients have auditors that experience an

\footnotetext{
${ }^{9}$ Specifically, audit firms may be motivated to avoid a Part II finding by the PCAOB, in which, the audit firms are publicly identified for having an audit quality issue that began as a Part I finding but was not adequately addressed. The regulator has access to private information about national office investments to solve Part I issues. In contrast, national office investments are not visible to the public in the case of scandals, so there may not be the same incentives to solve reputational concerns through national office involvement in those cases.

${ }^{10}$ The PCAOB is a private regulator created by the Sarbanes Oxley Act of 2002 to oversee the audits of publicly traded companies. Part of its regulatory duties include regular inspection of individual audit engagements for the largest four audit firms in our sample. Part I findings capture instances where the PCAOB inspectors note audit deficiencies or insufficient work in the audit as per applicable auditing standards. Part I findings provide an assessment of audit process and reveal issues in audit firms' methodologies that need to be addressed as soon as possible (Aobdia 2018; DeFond and Lennox 2017; Aobdia, Choudhary, and Sadka 2018; Aobdia, Choudhary, and Newberger 2019).
} 
increase in audit deficiency rates over 10 percent. We expect the effect of national office governance to be less sensitive to proximity when regulators find more deficiencies in the audit work performed by the audit firm. Accordingly, we add PARTI_INCREASE and an interaction between PARTI_INCREASE and each of the two PROXIMITY measures to model (1); a positive coefficient on the interaction would indicate that national office governance has a lower association with audit quality (i.e., less sensitive to the costs) in the presence of an increase in the audit deficiencies.

Table 5, Penal B reports the results of this test. We continue to find a negative coefficient on PROXIMITY_TO_NATIONAL and DIRECT $(\mathrm{p}<0.01)$, consistent with our prior analysis and the rejection of $\mathrm{H} 1$. We also find a positive and significant coefficient on the interaction ( $\mathrm{p}<0.05$ or better). Consistent with our predictions, this result suggests national office governance is less sensitive to travel costs proxied by proximity when they must improve their audit processes to address regulatory concerns. Overall, Table 5 provides additional supporting evidence that national office governance is associated with audit quality as its level varies with its sensitivity to costs.

\section{Channels of National Office Governance}

To further characterize the effects of national office governance, we examine the channels through which it may impact audit quality. First, we examine what happens when an external monitor, the PCAOB begins to inspect individual engagements. Part of the PCAOB's regulatory duties includes regular inspection of individual audit engagements for the largest four audit firms in our sample. We reason that when a new audit regulator is introduced, the impact of national office's role in monitoring to combat moral hazard will be attenuated. The external monitoring from the PCAOB will provide incentives of local offices to combat shirking because the inspection details and outcomes will be reported to the 
national audit firm, providing a new signal of individual engagement audit quality that is previously unavailable. Thus, if monitoring is one channel in which the national office governance impacts audit quality, we would expect the impact of national office monitoring on audit quality to decline when the moral hazard incentives are being addressed by an alternate avenue of monitoring that is not sensitive to the travel costs between national and local offices.

The first year of the PCAOB full inspection program is 2004, the results of which are first reported in $2005 ;{ }^{11}$ hence, we omit 2004 and 2005 from our sample since it is unclear if the impact of regulatory monitoring will occur right away or with some delay. We create an indicator, $P C A O B$, which equals to one for fiscal years beginning 2006 and onward, and zero for fiscal years before 2004 and add it to model (1). ${ }^{12}$ Because we expect national office governance to matter less once the external monitoring is initiated, our test of the monitoring channel is the interaction between PCAOB and each of the two PROXIMITY measures. A positive coefficient on the interaction is consistent with national office governance through monitoring having less of an impact on audit quality post the introduction of a new external monitor.

We report the results of this analysis in Table 6, Panel A. Similar to our analysis in Table 3, columns (1) and (2) report the impact to RESTATE_ALL and RESTATE_BIGR, respectively, with PROXIMITY_TO_NATIONAL and PROXIMITY_TO_NATIONAL*PCAOB. We replace PROXIMITY_TO_NATIONAL with DIRECT in columns (3) and (4). Consistent with results reported in Table 3, we continue to find a negative and significant coefficient on national office governance in all four columns

\footnotetext{
11 Although the PCAOB started inspections in 2003, the scale was very limited and the results of which were not reported until 2004. The first year of the expanded full inspections is 2004.

${ }^{12}$ As we are exploring the time-series variation in this set of tests, we exclude year fixed effects from model (1).
} 
$(\mathrm{p}<0.01$ or better); more governance means fewer restatements or better audit quality. Regarding the cross-sectional analysis, we find a positive but insignificant coefficient on the interaction term ( $\mathrm{p}>0.10)$ in columns (1) and (3) when explaining RESTATE_ALL, but a positive and significant coefficient on the interaction term ( $\mathrm{p}<0.05$ or better) in columns $(2)$ and (4) when explaining RESTATE_BIGR. The latter is consistent with our predictions that monitoring costs will matter less when a new, external party is introduced to monitor audit quality and combat moral hazard. This result provides evidence that national office governance through monitoring is one channel that impacts audit quality.

Second, we investigate cross-sectional variations where we expect the impact of knowledge transfer from national office on audit quality to be more (less) valuable. Following Beck et al. (2019), small offices that are proximate to a large office within the same audit firm have more knowledge sharing opportunities than those are not. Hence, we expect there is potentially greater importance of knowledge sharing from the national office, when a small office has fewer opportunities to obtain knowledge from another channel (i.e., the office is not in proximity to a within-firm large office). Accordingly, we define REMOTE as an indicator that equals one when the local office's proximity to the closest large office is in the lowest quartile (i.e., the farthest away from a within-firm large office) and add it to model (1). We also include the interaction of REMOTE with each of the two PROXIMITY measures, which is the test of whether national office governance impacts audits through knowledge sharing. A negative coefficient indicates knowledge sharing have an exacerbated effect on improving audit quality when the office is remote to a within-firm large office. ${ }^{13}$

The results are reported in Table 6, Panel B. Similar to our analysis in Table 3, columns (1) and (2) report the impact to RESTATE_ALL and RESTATE_BIGR, respectively,

\footnotetext{
${ }^{13} \mathrm{We}$ acknowledge that it is difficult to fully disentangle the impact of knowledge sharing versus monitoring by the national office using this cross-sectional test as a small office may also receive monitoring from a within-firm large office (Beck et al. 2019).
} 
with PROXIMITY_TO_NATIONAL and PROXIMITY_TO_NATIONAL*REMOTE.We replace PROXIMITY_TO_NATIONAL with DIRECT in columns (3) and (4). Consistent with our prior analysis, we continue to find a negative coefficient on PROXIMITY_TO_NATIONAL and DIRECT ( $\mathrm{p}<0.10$ or better in columns 1, 2, and 4). Consistent with our cross-sectional predictions, we also find a negative coefficient on the interaction between REMOTE and PROXIMITY_TO_NATIONAL or DIRECT ( $\mathrm{p}<0.10$ or better except in column 2), consistent with small offices that are remote to a within-firm large office benefiting more from knowledge transfer from the national office.

Parallel to the arguments above, larger offices have a bigger pool of local experts such that they do not benefit from knowledge transfer with national office as much. We include an indicator, LARGE_OFFICE, which equals one when SIZE_AUDITOR (i.e., the total audit fees generated by an audit office in a year) is in the highest quartile of the sample, and zero otherwise. We interact LARGE_OFFICE with each of the two PROXIMITY measures and report the results in Table 6, Panel C. We expect and find that large offices benefit less from knowledge transfer as we report a positive coefficient on the interaction term $(\mathrm{p}<0.10$ or better, except column 1). The results in Table 6, Panel B and C are consistent with knowledge transfer from the national office being more (less) valuable to remote (large) local offices.

\section{Falsification Tests on Small Audit Firms}

As suggested by theoretical work that investigates the relationship between partnership size and incentives (e.g., Huddart and Liang 2005), larger partnerships may invest more in national office governance because their problems from moral hazard and benefits from knowledge sharing are greater. Hence, in this section, we compare the impact of national office governance on audit quality in small audit firms (tier 2) to larger audit firms. 
We first expand our full sample to include five lower-tier audit firms (i.e., Grant Thornton, BDO Seidman, Crowe Chizek, Plante \& Moran, and McGladrey \& Pullen). We verify historical national office locations of these firms from Accounting Today Top 100 Firms that are published annually over our sample period. This data indicates the following changes in national office locations in our sample period: Crowe Chizek moved its national office from Indianapolis, IN to South Bend, IN in 2005, then moved to Oakbrook Terrace, IL in 2008, and then moved to Chicago, IL in 2013. McGladrey \& Pullen moved its national office from Bloomington, MN to Chicago, IL in 2013. Among these firms, BDO Seidman also has its national office located in New York, NY, similar to the Big 4 firms.

Next, we report descriptive statistics to establish the different operating structure of the Big 4 versus smaller audit firms in Table 7, Panel A. First, we find that the mean number of total local offices per audit firm of the Big 4 in our sample is 70, which is much larger than the smaller audit firms with a mean of 22 . Because there are many more local offices for the Big 4 compared to the smaller audit firms, Big 4 firms encounter larger moral hazard issues (Huddart and Liang 2005). Second, while the difference in PROXIMITY_TO_CLIENT (i.e., the proximity between the local office and its client) between the two groups of audit firms is economically small (-0.04 or 40 miles), the difference in the proximity between the national office and local office (i.e., PROXIMITY_TO_NATIONAL) across the two groups is quite large ( 0.30 or 300 miles). Not only are the distances between the national and local office greater for the big 4 audit firms versus the smaller firms, but the geographical dispersion is also greater. The standard deviation of PROXIMITY_TO_NATIONAL is 0.88 for Big 4 firms versus 0.63 for smaller audit firms, reported in Table 7, Panel B. Greater value and dispersion of the distances between national and local office make it more challenging for national offices to monitor local offices and transfer knowledge. Collectively, these descriptive statistics highlight the potential need for national office governance is higher for Big 4 audit 
firms compared to lower-tier audit firms. Moreover, our discussions with practitioners provide additional anecdotal support that the national office roles of the smaller audit firms are less extensive. Hence, we expect there to be less or no effect of national office proximity on audit quality of local offices among smaller audit firms.

Next, we perform multivariate analyses among the Big 4 samples used in our primary analysis and add the sample of smaller audit firms (adding $n=4,241$ observations to the full sample). ${ }^{14}$ We add an indicator, SMALL_FIRM, which equals one if the audit firm is one of the five smaller audit firms, and zero if the audit firm is one of the Big 4 audit firms to model (1). We also interact SMALL_FIRM with each of the two PROXIMITY measures. A positive coefficient on the interaction is consistent with less impact of national office governance on audit quality in the smaller audit firms, as predicted by theory.

We report these results in Table 7, Panel C. Consistent with our prior results, we continue to report negative coefficients on PROXIMITY_TO_NATIONAL and DIRECT for all four columns ( $p<0.01$ or better except column 3 ). We find a positive coefficient on the interaction between SMALL_FIRM and PROXIMITY_TO_NATIONAL or DIRECT in all four columns ( $\mathrm{p}<0.10$ or better, except column 1). Consistent with theory (e.g., Huddart and Liang 2005), these results suggest that the smaller audit firms do not realize the same magnitude of benefits from national office governance on audit quality. In untabulated tests, we estimate the effect of PROXIMITY on small audit firms only using our model in equation (1) and find no significant impact of either measure on the propensity of restatements, except a positive coefficient on PROXIMITY_TO_NATIONAL for RESTATE_ALL ( $\mathrm{p}<0.10)$. Thus,

\footnotetext{
${ }^{14}$ We eliminate 8,518 observations when using DIRECT measure in Table 7 Panel C, columns (3) and (4) due to the proximity between national and local office being less than 200 miles. Again, this is because for these observations where the audit offices are close to their national offices, air travel may not be the optimal means of transportation. In this case, using flight patterns are unlikely to capture cost of national office involvement.
} 
we fail to find an association between proximity to national office and audit quality in the group of smaller audit firms that are less likely to invest in national office governance.

\section{Robustness Tests}

\section{Local Shocks and the Introduction of Direct Flights}

When using the variation in flight patterns between the national and local audit offices to measure national office monitoring costs, an underlying assumption we made is that the introduction of frequent direct airline routes is exogenous in our setting. However, if there are (omitted) factors that are driving both the introduction of new airline routes and office-level audit quality, then any relationship between the two could be spurious. For example, if the local economy of the area where an audit office locates is booming, airlines may find it more attractive to introduce new direct flights to the area. At the same time, auditors may find the area more attractive to work at so that the local office can obtain more competent auditors. Ideally, we would add 107 MSA fixed effects for each of 18 years in our sample, or 1,926 fixed effects. Because all the firms have national offices in the same general area, we are unable to exploit much variation in restatements with this type of research design. Instead, we follow Bertrand and Mullainathan (2003) and account for local shocks by including MSAYear controls, which are computed as the mean of the dependent variable (RESTATE_ALL and RESTATE_BIGR, respectively) in the audit office's MSA in a given year, excluding the office of interest. The results are presented in Table 8 . We continue to report a negative coefficient on DIRECT ( $\mathrm{p}<0.05$ or better), consistent with our main analysis and conclusions to reject $\mathrm{H} 1$.

\section{Airline Price as an Alternative Measure of National Office Governance}

In our main tests, we used PROXIMITY_TO_NATIONAL and DIRECT as the proximity-based measures of the costs of national office governance. This assumes that closer 
proximity or shorter flights have less costs, with national office governance costs measured in travel time. An alternative is to measure national office governance costs in the price of flights. This assumes that audit firms do not have unlimited budgets to support national office governance; rather, they are sensitive to cost in dollars as well. We obtain data on flight prices from the U.S. Department of Transportation Airline Origin and Destination Survey (DB1B), which represents a 10 percent sample of airline tickets from reporting carriers collected by the Office of Airline Information of the Bureau of Transportation Statistics. ${ }^{15} \mathrm{We}$ estimate PRICE as the average flight price for each location pair by year. Similar to our analysis using DIRECT, we eliminate 4,468 observations within 200 miles of the national office as personnel may avoid taking flights for shorter distances. We report the results in Table 9. We find a positive coefficient on PRICE $(\mathrm{p}<0.01$ ), consistent with more expensive flights representing less national office governance, leading to more restatements or worse audit quality.

\section{CONCLUSION}

The geographically decentralized partnership structure of audit firms imposes costs due to moral hazard and resource constraints. We find evidence that large audit firms mitigate these costs by involving national offices to play a centralized governance role. More specifically, the national office can monitor and share knowledge with local offices to address the downside costs of the decentralized structure on audit quality. We find that national office proximity (in distance) to local offices, which proxies for national office governance, is associated with better audit quality. To enhance causal inference and exploit an exogenous source of variation, we expand our analyses to proxy for national office governance using the introduction of frequent direct airline routes and find consistent evidence of better audit

\footnotetext{
${ }^{15}$ We thank Alice Bohaime for sharing her compiled data with us.
} 
quality, or lower restatements. Additional time series analysis shows that the effect appears when direct flights are introduced and remain as direct flights continue. Our results are incremental to controlling for other proximity-based measures, such as the distance from the SEC office, the distance between the audit office and its client, and the distance from a within-firm large office.

Cross-sectional analyses confirm that the impact of national office proximity on restatement likelihood is exacerbated in the presence of time constraints faced by the national office and tempered in the presence of the need to address regulator-identified audit deficiencies. We also provide evidence that both roles the national office plays -- monitoring and knowledge sharing are important for audit quality through additional time-series and cross-sectional analyses. Using a larger sample including lower-tier audit firms, we find that smaller audit firms benefit less from national office governance, consistent with theory suggesting that smaller partnership structures have less moral hazard costs and less knowledge transfer benefits from national office governance. Our results are robust to controlling for local shocks that could potentially drive the introduction of the new airline routes. Overall, our study proposes a new venue that develops audit quality among auditors and highlights the benefits of national office governance. 


\section{REFERENCES}

Aobdia, D. 2018. The impact of the PCAOB individual engagement inspection processPreliminary evidence. The Accounting Review 93 (4): 53-80.

Aobdia, D., P. Choudhary, and N. Newberger. 2019. The Economics of Audit Production: What Matters for Audit Quality? Available at SSRN 3300277.

Aobdia, D., P. Choudhary, and G. Sadka. 2018. Do auditors correctly identify and assess internal control deficiencies? Evidence from the PCAOB data. Evidence from the PCAOB Data (April 19, 2018). Georgetown McDonough School of Business Research Paper.

Ashraf, M., P. N. Michas, and D. Russomanno. 2019. The Impact of Audit Committee Information Technology Expertise on the Reliability and Timeliness of Financial Reporting. The Accounting Review.

Audretsch, D. B., and M. P. Feldman. 1996. R\&D spillovers and the geography of innovation and production. The American Economic Review 86 (3): 630-640.

Audretsch, D. B., and P. E. Stephan. 1996. Company-scientist locational links: The case of biotechnology. The American Economic Review 86 (3): 641-652.

Ayers, B. C., S. Ramalingegowda, and P. E. Yeung. 2011. Hometown advantage: The effects of monitoring institution location on financial reporting discretion. Journal of Accounting and Economics 52 (1): 41-61.

Balsam, S., J. Krishnan, and J. S. Yang. 2003. Auditor industry specialization and earnings quality. Auditing: A Journal of Practice \& Theory 22 (2): 71-97.

Beck, M. J., J. R. Francis, and J. L. Gunn. 2018. Public company audits and city-specific labor characteristics. Contemporary Accounting Research 35 (1): 394-433.

Beck, M. J., J. L. Gunn, and N. Hallman. 2019. The geographic decentralization of audit firms and audit quality. Journal of Accounting and Economics 68 (1): 101234.

Bedard, J. C., K. M. Johnstone, and E. F. Smith. 2010. Audit quality indicators: A status update on possible public disclosures and insights from audit practice. Current Issues in Auditing 4 (1): C12-C19.

Bernstein, S., X. Giroud, and R. R. Townsend. 2016. The impact of venture capital monitoring. The Journal of Finance 71 (4): 1591-1622.

Bertrand, M., and S. Mullainathan. 2003. Enjoying the quiet life? Corporate governance and managerial preferences. Journal of political Economy 111 (5): 1043-1075.

Brooks, L. Z., and M. D. Yu. 2013. Why Hire a Big 4 Auditor 500 Miles Away? Available at SSRN 2784648.

Carcello, J. V, R. H. Hermanson, and N. T. McGrath. 1992. Audit quality attributes: The perceptions of audit partners, preparers, and financial statement users. Auditing 11 (1): 1.

Causholli, M., and W. R. Knechel. 2012. An examination of the credence attributes of an audit. Accounting Horizons 26 (4): 631-656.

Chhaochharia, V., A. Kumar, and A. Niessen-Ruenzi. 2012. Local investors and corporate governance. Journal of Accounting and Economics 54 (1): 42-67.

Choi, J.-H., J.-B. Kim, A. A. Qiu, and Y. Zang. 2012. Geographic proximity between auditor and client: How does it impact audit quality? Auditing: A Journal of Practice \& Theory 31 (2): 43-72.

Choudhary, P., K. Merkley, and K. Schipper. 2019. Auditors' quantitative materiality judgments: Properties and implications for financial reporting reliability. Journal of Accounting Research 57 (5): 1303-1351.

Christie, A. A., M. P. Joye, and R. L. Watts. 2003. Decentralization of the firm: theory and evidence. Journal of Corporate Finance 9 (1): 3-36.

Chaney, P. K., and K. L. Philipich. 2002. Shredded reputation: The cost of audit failure. Journal of Accounting Research 40 (4): 1221-1245. 
Cohen, J. R., U. Hoitash, G. Krishnamoorthy, and A. M. Wright. 2014. The effect of audit committee industry expertise on monitoring the financial reporting process. The Accounting Review 89 (1): 243-273.

Coval, J. D., and T. J. Moskowitz. 2001. The geography of investment: Informed trading and asset prices. Journal of political Economy 109 (4): 811-841.

DeAngelo, L. E. 1981. Auditor size and audit quality. Journal of Accounting and Economics 3 (3): 183-199.

Dechow, P. M., W. Ge, C. R. Larson, and R. G. Sloan. 2011. Predicting material accounting misstatements. Contemporary Accounting Research 28 (1): 17-82.

DeFond, M., J. R. Francis, and N. J. Hallman. 2018. Awareness of SEC enforcement and auditor reporting decisions. Contemporary Accounting Research 35 (1): 277-313.

DeFond, M. L., and C. S. Lennox. 2017. Do PCAOB inspections improve the quality of internal control audits? Journal of Accounting Research 55 (3): 591-627.

DeFond, M., and J. Zhang. 2014. A review of archival auditing research. Journal of Accounting and Economics 58 (2-3): 275-326.

Degryse, H., and S. Ongena. 2005. Distance, lending relationships, and competition. The Journal of Finance 60 (1): 231-266.

EY. 2019. Our commitment to audit quality. Available at: https://www.ey.com/en_us/assurance/our-commitment-to-audit-quality-ernst-andyoung-1lp-2019-report

Ferguson, A., J. R. Francis, and D. J. Stokes. 2003. The effects of firm-wide and office-level industry expertise on audit pricing. The Accounting Review 78 (2): 429-448.

Francis, J. R., E. L. Maydew, and H. C. Sparks. 1999. The role of Big 6 auditors in the credible reporting of accruals. Auditing: a Journal of Practice \& theory 18 (2): 17-34.

Francis, J. R., P. N. Michas, and M. D. Yu. 2013. Office size of Big 4 auditors and client restatements. Contemporary Accounting Research 30 (4): 1626-1661.

Francis, J. R., K. Reichelt, and D. Wang. 2005. The pricing of national and city-specific reputations for industry expertise in the US audit market. The Accounting Review 80 (1): $113-136$.

Francis, J. R., and M. D. Yu. 2009. Big 4 office size and audit quality. The Accounting Review 84 (5): 1521-1552.

Gertler, M. S. 2003. Tacit knowledge and the economic geography of context, or the undefinable tacitness of being (there). Journal of Economic Geography 3 (1): 75-99.

Gipper, B., C. Leuz, and M. Maffett. 2019. Public Oversight and Reporting Credibility: Evidence from the PCAOB Audit Inspection Regime. The Review of Financial Studies.

Giroud, X. 2013. Proximity and investment: Evidence from plant-level data. The Quarterly Journal of Economics 128 (2): 861-915.

Hanes, D. R. 2013. Geographically distributed audit work: Theoretical considerations and future directions. Journal of Accounting Literature 32 (1): 1-29.

Hennes, K. M., A. J. Leone, and B. P. Miller. 2008. The importance of distinguishing errors from irregularities in restatement research: The case of restatements and CEO/CFO turnover. The Accounting Review 83 (6): 1487-1519.

Holmstrom, B. 1982. Moral hazard in teams. The Bell Journal of Economics: 324-340.

Huddart, S., and P. J. Liang. 2005. Profit sharing and monitoring in partnerships. Journal of Accounting and Economics 40 (1-3): 153-187.

IOSCO. 2009. Consultation report: Transparency of firms that audit public companies. Available at: https://www.iosco.org/library/pubdocs/pdf/IOSCOPD302.pdf

Jensen, K., J.-M. Kim, and H. Yi. 2015. The geography of US auditors: information quality and monitoring costs by local versus non-local auditors. Review of Quantitative Finance and Accounting 44 (3): 513-549. 
John, K., A. Knyazeva, and D. Knyazeva. 2011. Does geography matter? Firm location and corporate payout policy. Journal of Financial Economics 101 (3): 533-551.

Kedia, S., and S. Rajgopal. 2011. Do the SEC's enforcement preferences affect corporate misconduct? Journal of Accounting and Economics 51 (3): 259-278.

Kinney Jr, W. R., Z. Palmrose, and S. Scholz. 2004. Auditor independence, non-audit services, and restatements: Was the US government right? Journal of Accounting Research 42 (3): 561-588.

Knechel, W. R., L. Niemi, and M. Zerni. 2013. Empirical evidence on the implicit determinants of compensation in Big 4 audit partnerships. Journal of Accounting Research 51 (2): 349387.

Krishnan, G. V. 2003. Does Big 6 auditor industry expertise constrain earnings management? Accounting Horizons 17: 1-16.

Levin, J., and S. Tadelis. 2005. Profit sharing and the role of professional partnerships. The Quarterly Journal of Economics 120 (1): 131-171.

Li, C. 2009. Does client importance affect auditor independence at the office level? Empirical evidence from going-concern opinions. Contemporary Accounting Research 26 (1): 201230.

Maijoor, S., and A. Vanstraelen. 2012. "Research opportunities in auditing in the EU," revisited. Auditing: A Journal of Practice \& Theory 31 (1): 115-126.

Malloy, C. J. 2005. The geography of equity analysis. The Journal of Finance 60 (2): 719-755.

Myers, J. N., L. A. Myers, and T. C. Omer. 2003. Exploring the term of the auditor-client relationship and the quality of earnings: A case for mandatory auditor rotation? The Accounting Review 78 (3): 779-799.

Public Company Accounting Oversight Board (PCAOB). 2016. Rule 3211: Auditor Reporting of Certain Audit Participants. Washington, D.C.: PCAOB.

Public Company Accounting Oversight Board (PCAOB). 2017. AS 3101: The Auditor's Report on an Audit of Financial Statements When the Auditor Expresses an Unqualified Opinion. Washington, D.C.: PCAOB.

Petersen, M. A. 2009. Estimating standard errors in finance panel data sets: Comparing approaches. The Review of Financial Studies 22 (1): 435-480.

Petersen, M. A., and R. G. Rajan. 2002. Does distance still matter? The information revolution in small business lending. The journal of Finance 57 (6): 2533-2570.

PwC. 2019. 2019 Audit Quality Report. Available at: https://www.pwc.com/us/en/services/audit-assurance/library/audit-quality-report.html

Rajgopal, S., S. Srinivasan, and X. Zheng. Measuring Audit Quality. Review of Accounting Studies.

Reichelt, K. J., and D. Wang. 2010. National and office-specific measures of auditor industry expertise and effects on audit quality. Journal of Accounting Research 48 (3): 647-686.

Reynolds, J. K., and J. R. Francis. 2000. Does size matter? The influence of large clients on office-level auditor reporting decisions. Journal of accounting and economics 30 (3): $375-400$.

Richardson, S. A., R. G. Sloan, M. T. Soliman, and I. Tuna. 2005. Accrual reliability, earnings persistence and stock prices. Journal of Accounting and Economics 39 (3): 437-485.

Schroeder, J. H. 2016. The impact of audit completeness and quality on earnings announcement GAAP disclosures. The Accounting Review 91 (2): 677-705.

Seavey, S. E., M. J. Imhof, and T. J. Westfall. 2018. Audit firms as networks of offices. Auditing: A Journal of Practice \& Theory 37 (3): 211-242.

Skinner, D. J., and R. G. Sloan. 2002. Earnings surprises, growth expectations, and stock returns or don't let an earnings torpedo sink your portfolio. Review of Accounting Studies 7 (2-3): 289-312. 
Stein, J. C. 2002. Information production and capital allocation: Decentralized versus hierarchical firms. The Journal of Finance 57 (5): 1891-1921.

Teoh, S. H., and T. J. Wong. 1993. Perceived auditor quality and the earnings response coefficient. The Accounting Review: 346-366.

Thammasiri, W. 2014. Auditor-client distance: determinants and implications for audit quality. Available at: http://citeseerx.ist.psu.edu/viewdoc/download?doi=10.1.1.999.8417\&rep=rep1\&type=pd $\underline{\mathrm{f}}$

Wallman, S. M. H. 1996. The future of accounting, part III: Reliability and auditor independence. Accounting Horizons 10 (4): 76.

Weber, J., M. Willenborg, and J. Zhang. 2008. Does auditor reputation matter? The case of KPMG Germany and ComROAD AG. Journal of Accounting Research 46 (4): 941-972. 


\section{APPENDIX A \\ Variable Definitions}

Variable

Definition

Dependent variables

RESTATE_ALL

RESTATE_BIGR

Test Variables

PROXIMITY_TO_NATIONAL

DIRECT

DIRECT_INTRO_PRIOR

DIRECT_INTRO

DIRECT_INTRO_POST

DIRECT_CONT

PROXIMITY_TO_CLIENT

PROXIMITY_TO_SEC

\section{Client Firm Controls}

SIZE_CLIENT

CASH_FLOWS

LOSS

$D E B T$

RSST_ACC

CHG_REC

CHG_INV

CHG_CASH_SALE is an indicator variable equals one if a client-year's $10-\mathrm{K}$ filing was restated subsequently (including both non-reliance restatements under Item 4.02 and other restatements), and zero otherwise.

is an indicator variable equals one if a client-year's $10-\mathrm{K}$ filing was restated and an Item 4.02 non-reliance misstatement disclosure was issued in an 8-K filing, and zero otherwise.

is the total distance (in thousands of miles) between the opinion signing audit office and the national office of the firm multiplied by negative one.

is an indicator variable that equals one when a direct airline route with at least 100 flights per year between the opinion signing audit office and its national office has been introduced by time $t$, and zero otherwise.

is an indicator variable that equals one if a direct airline route with at least 100 flights per year between the opinion signing audit office and its national office is introduced in $\mathrm{t}+1$, and zero otherwise.

is an indicator variable that equals one if a direct airline route with at least 100 flights per year between the opinion signing audit office and its national office is introduced in $\mathrm{t}$, and zero otherwise.

is an indicator variable that equals one if a direct airline route with at least 100 flights per year between the opinion signing audit office and its national office is introduced in $\mathrm{t}-1$, and zero otherwise.

is an indicator variable that equals one a direct airline route with at least 100 flights per year between the opinion signing audit office and its national office has been introduced in $\mathrm{t}-2$ or before, and the direct flight has not been terminated, and 0 otherwise.

is the total distance (in thousands of miles) between the opinion signing audit office and the closest large office of the same audit firm multiplied by negative one.

Large office is defined as an office in the top ten percent of average audit fees within each audit firm during our sample period.

is the total distance (in thousands of miles) between the opinion signing audit office and the client headquarters multiplied by negative one.

is the total distance (in thousands of miles) between the opinion signing audit office and the closest SEC regional office multiplied by negative one. SEC office locations are available on SEC.gov.

is the natural log of a client's total assets (in millions of dollars) in year t. is total client firm cash flows from operations scaled by total assets in year $t$. is an indicator variable that equals one if net income is negative in year $t$, and zero otherwise.

is total client-firm debt scaled by total assets in year $\mathrm{t}$.

is the accruals measure developed by Richardson, Sloan, Soliman, and Tuna (2005) that is the sum of working capital accruals, changes in long-term operating assets, and long-term operating liabilities, scaled by average total assets.

is the change in accounts receivables from year $\mathrm{t}-1$ to year $\mathrm{t}$, scaled by total assets in year $t$.

is the percentage change in inventories from year $t-1$ to year $t$.

is the percentage change in cash sales from year $\mathrm{t}-1$ to year $\mathrm{t}$. 
CHG_EARN

ISSUE

CHG_EMP

OP_LEASES

$B T M$

ABNORMAL_RET

TENURE

AUDITOR_CHANGE

$G C$

Auditor Controls

SIZE_AUDITOR

AUDIT

NON_AUDIT

INFLUENCE

NATIONAL_LEADER

CITY_LEADER

City Controls

POPULATION

GDPPC

Other Variables

SCANDAL

PARTI_INCREASE

PCAOB

REMOTE

LARGE_OFFICE

SMALL_FIRM

PRICE is the percentage change in earnings from year $\mathrm{t}-1$ to year $\mathrm{t}$.

is an indicator variable that equals one if a client issued new debt or equity in year $\mathrm{t}$, and zero otherwise.

is the abnormal change in the number of employees, which is calculated as the percentage change in the number of employees less the percentage change in total assets from year t- 1 to year $t$.

is the change in the present value of future noncancelable operating lease obligations from year $\mathrm{t}-1$ to year $\mathrm{t}$, scaled by total assets in year $\mathrm{t}$.

is the ratio of book value of equity to market value of equity in year $t$.

is the prior 12-month buy-and-hold return adjusted for CRSP value-weighted market returns in year $\mathrm{t}$.

is the number of consecutive years that the same audit firm has issued an opinion on the company's annual financial statements.

is an indicator variable that equals one if a client changes its auditor in year $t$, and zero otherwise.

is an indicator variable that equals one if the client firm received a going concern opinion in year $t$, and zero otherwise.

is the natural $\log$ of total audit fees generated in year $t$ by the opinion signing audit office.

is a client's natural log of audit fees in year $\mathrm{t}$.

is a client's natural log of non-audit fees in year t.

is the ratio of a client's total fees (audit fees plus non-audit fees) scaled by the aggregated client fees generated by the opinion signing audit office in year $t$.

is an indicator variable that equals one if the opinion signing audit office is the number one auditor in an industry in terms of aggregated audit fees in year $\mathrm{t}$, and zero otherwise.

is an indicator variable that equals one if the opinion signing audit office is the number one auditor in terms of aggregated client audit fees in an industry within that city in year $\mathrm{t}$, and zero otherwise.

is the natural $\log$ of the population of the MSA in which the opinion signing audit office is located in year $t$.

is the natural log of the GDP per capita of the MSA in which the opinion signing audit office is located in year t.

is an indicator variable that equals one if the audit firm is in the year of the revelation of major audit scandal(s) and the two years after, and zero otherwise.

is an indicator variable that equals one if the ratio of total part I findings to total engagements reviewed by PCAOB increases by over 10 percent from t1 to $t$, and zero otherwise.

is an indicator variable that equals one for fiscal years beginning 2006 and onward, and zero for fiscal years before 2004.

is an indicator variable that equals one if the local office's proximity to the closest large office is in the smallest quartile (i.e., the farthest away from a within-firm large office), and zero otherwise.

is an indicator variable that equals one if the SIZE_AUDITOR of the opinion signing audit office is in the highest quartile of the sample, and zero otherwise. is an indicator variable that equals one if the audit firm is one of the five smaller audit firms (i.e., Grant Thornton, BDO Seidman, Crowe Chizek, Plante \& Moran, and McGladrey \& Pullen), and zero if the audit firm is one of the Big 4 firms.

is the annual average ticket price between two locations estimated using airline price data from the US Department of Transportation Airline Origin and Destination Survey (DB1B). 


\section{APPENDIX B}

Major Audit Scandals from 2000 to 2017

\begin{tabular}{lll} 
Event & Audit Firm & $\begin{array}{l}\text { Year of } \\
\text { Revelation }\end{array}$ \\
\hline Xerox & KPMG & 2001 \\
Tyco & PwC & 2002 \\
Health South & Deloitte & 2003 \\
Parmalat & Deloitte & 2004 \\
Adelphia & Deloitte & 2005 \\
Tax shelter issues & KPMG & 2005 \\
AIG & PwC & 2005 \\
PCAOB Part II report & Deloitte & 2007 \\
Dell & PwC & 2007 \\
Lehman Brothers Repo 105 transactions & EY & 2008 \\
PCAOB list scandal & KPMG & 2017 \\
Colonial Bank & PwC & 2019 \\
\hline
\end{tabular}


TABLE 1

\section{Sample Selection}

Client-Years

Firm-year observations of U.S. Big 4 audit firms from 2000 through 2017

(Compustat-Audit Analytics merged sample)

63,012

Less: missing geological information to calculate proximity-based measures

Less: missing data for client firm controls

Less: missing data for auditor controls

Less: missing data for city controls

Full sample

Less: the distance between the audit office and its national office is less than 200 miles

Notes: The full sample is comprised of all firm-year observations of U.S. Big 4 audit firms from 2000 through 2017 available in the Compustat-Audit Analytics merged sample for which data is available for restatements, proximity measures, as well as other control variables. When using DIRECT to proxy for national office governance, we eliminate observations have local offices located within 200 miles from the national office and obtain the sample for DIRECT. 
FIGURE 1

PwC Local Offices in U.S. in 2017

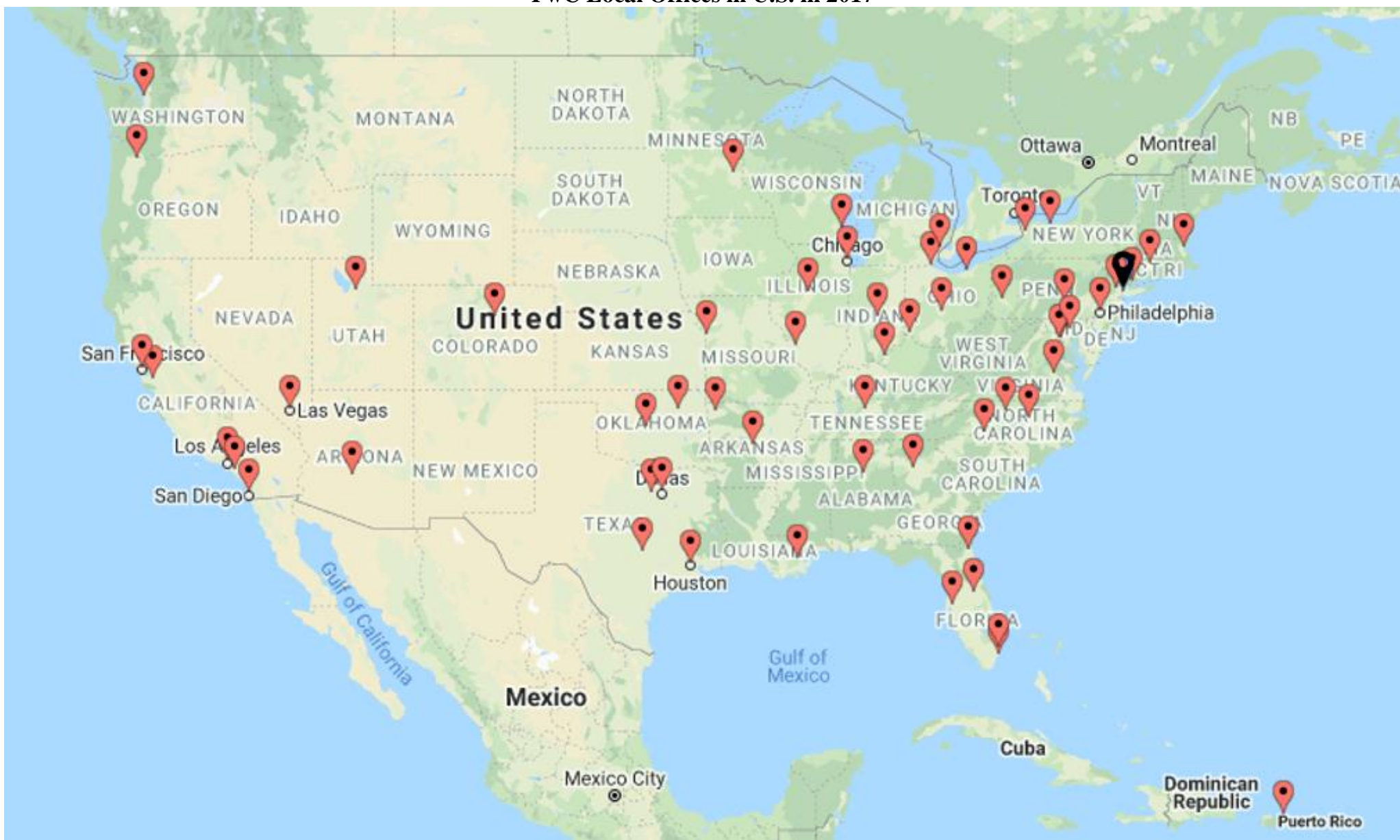

Notes: This figure plots the locations of all PwC U.S. practice offices in 2017. The location of the national office (New York, NY) is marked in black. 


\begin{tabular}{|c|c|c|c|c|c|c|c|}
\hline \multicolumn{8}{|c|}{$\begin{array}{cc}\text { TABLE 2 } \\
\text { Descriptive Statistics }\end{array}$} \\
\hline \multicolumn{8}{|c|}{ Panel A: Descriptive Statistics for Full Sample } \\
\hline Variable & & $\mathbf{N}$ & Mean & Std & 25th & Median & 75th \\
\hline \multirow{2}{*}{$\begin{array}{l}\text { Dependent } \\
\text { Variables }\end{array}$} & RESTATE_ALL & 32,987 & 0.20 & 0.40 & 0.00 & 0.00 & 0.00 \\
\hline & RESTATE_BIGR & 32,987 & 0.09 & 0.28 & 0.00 & 0.00 & 0.00 \\
\hline \multirow{6}{*}{$\begin{array}{c}\text { Test } \\
\text { Variables }\end{array}$} & PROXIMITY_TO_NATIONAL & 32,987 & -1.05 & 0.88 & -1.63 & -0.75 & -0.21 \\
\hline & DIRECT & 32,987 & 0.32 & 0.47 & 0.00 & 0.00 & 1.00 \\
\hline & DIRECT_INTRO_PRIOR & 32,987 & 0.05 & 0.21 & 0.00 & 0.00 & 0.00 \\
\hline & DIRECT_INTRO & 32,987 & 0.05 & 0.23 & 0.00 & 0.00 & 0.00 \\
\hline & DIRECT_INTRO_POST & 32,987 & 0.07 & 0.25 & 0.00 & 0.00 & 0.00 \\
\hline & DIRECT_CONT & 32,987 & 0.70 & 0.46 & 0.00 & 1.00 & 1.00 \\
\hline \multirow{3}{*}{$\begin{array}{l}\text { Proximity } \\
\text { Controls }\end{array}$} & PROXIMITY_TO_LARGE & 32,987 & -0.19 & 0.22 & -0.32 & -0.11 & 0.00 \\
\hline & PROXIMITY_TO_CLIENT & 32,987 & -0.12 & 0.36 & -0.03 & -0.01 & -0.01 \\
\hline & PROXIMITY_TO_SEC & 32,987 & -0.14 & 0.16 & -0.24 & -0.04 & 0.00 \\
\hline \multirow{17}{*}{$\begin{array}{l}\text { Client } \\
\text { Firm } \\
\text { Controls }\end{array}$} & SIZE_CLIENT & 32,987 & 7.02 & 1.98 & 5.64 & 6.98 & 8.32 \\
\hline & CASH_FLOWS & 32,987 & 0.06 & 0.13 & 0.02 & 0.08 & 0.13 \\
\hline & $\operatorname{LOSS}$ & 32,987 & 0.27 & 0.44 & 0.00 & 0.00 & 1.00 \\
\hline & $D E B T$ & 32,987 & 0.55 & 0.26 & 0.36 & 0.55 & 0.73 \\
\hline & $R S S T \_A C C$ & 32,987 & 0.02 & 0.16 & -0.03 & 0.02 & 0.07 \\
\hline & $C H G_{-} R E C$ & 32,987 & 0.01 & 0.05 & -0.01 & 0.00 & 0.02 \\
\hline & $C H G \_I N V$ & 32,987 & 0.14 & 0.60 & -0.09 & 0.05 & 0.21 \\
\hline & CHG_CASH_SALE & 32,987 & 0.09 & 0.60 & -0.05 & 0.06 & 0.18 \\
\hline & CHG_EARN & 32,987 & -0.16 & 3.38 & -0.61 & 0.00 & 0.36 \\
\hline & ISSUE & 32,987 & 0.94 & 0.24 & 1.00 & 1.00 & 1.00 \\
\hline & CHG_EMP & 32,987 & -0.05 & 0.24 & -0.11 & -0.03 & 0.05 \\
\hline & OP_LEASES & 32,987 & 0.00 & 0.03 & 0.00 & 0.00 & 0.01 \\
\hline & $B T M$ & 32,987 & 0.58 & 0.56 & 0.27 & 0.48 & 0.76 \\
\hline & ABNORMAL_RET & 32,987 & 0.07 & 0.51 & -0.22 & -0.01 & 0.24 \\
\hline & TENURE & 32,987 & 6.03 & 4.61 & 2.00 & 5.00 & 9.00 \\
\hline & AUDITOR_CHANGE & 32,987 & 0.05 & 0.22 & 0.00 & 0.00 & 0.00 \\
\hline & $G C$ & 32,987 & 0.02 & 0.14 & 0.00 & 0.00 & 0.00 \\
\hline \multirow{6}{*}{$\begin{array}{l}\text { Auditor } \\
\text { Controls }\end{array}$} & SIZE_AUDITOR & 32,987 & 17.42 & 1.37 & 16.52 & 17.60 & 18.44 \\
\hline & $A U D I T$ & 32,987 & 13.94 & 1.24 & 13.13 & 13.95 & 14.76 \\
\hline & $N O N \_A U D I T$ & 32,987 & 11.67 & 3.27 & 11.05 & 12.28 & 13.41 \\
\hline & INFLUENCE & 32,987 & 0.08 & 0.15 & 0.01 & 0.03 & 0.08 \\
\hline & NATIONAL_LEADER & 32,987 & 0.33 & 0.47 & 0.00 & 0.00 & 1.00 \\
\hline & CITY_LEADER & 32,987 & 0.66 & 0.47 & 0.00 & 1.00 & 1.00 \\
\hline \multirow{2}{*}{$\begin{array}{c}\text { City } \\
\text { Controls }\end{array}$} & POPULATION & 32,987 & 15.04 & 0.92 & 14.37 & 15.02 & 15.55 \\
\hline & $G D P P C$ & 32,987 & 10.99 & 0.20 & 10.86 & 10.98 & 11.11 \\
\hline \multirow{7}{*}{$\begin{array}{c}\text { Other } \\
\text { Variables }\end{array}$} & SCANDAL & 32,987 & 0.37 & 0.48 & 0.00 & 0.00 & 1.00 \\
\hline & PARTI_INCREASE & 32,987 & 0.18 & 0.38 & 0.00 & 0.00 & 0.00 \\
\hline & $P C A O B$ & 28,586 & 0.72 & 0.45 & 0.00 & 1.00 & 1.00 \\
\hline & REMOTE & 32,987 & 0.25 & 0.43 & 0.00 & 0.00 & 0.00 \\
\hline & LARGE_OFFICE & 32,987 & 0.25 & 0.43 & 0.00 & 0.00 & 0.00 \\
\hline & SMALL_FIRM & 37,228 & 0.11 & 0.32 & 0.00 & 0.00 & 0.00 \\
\hline & PRICE & 20,781 & 337.80 & 168.80 & 221.20 & 297.10 & 387.10 \\
\hline
\end{tabular}


TABLE 2 (continued)

Panel B: Comparison between client-year variables with and without direct airline routes

\begin{tabular}{|c|c|c|c|c|c|}
\hline \multirow[t]{2}{*}{ Variable } & & \multirow{2}{*}{$\begin{array}{r}\text { Non-direct } \\
17,125\end{array}$} & \multirow{2}{*}{$\begin{array}{r}\text { Direct } \\
8,174\end{array}$} & \multicolumn{2}{|c|}{$\begin{array}{c}\text { Difference } \\
\text { (Non-direct -Direct) }\end{array}$} \\
\hline & $\mathrm{N}$ & & & & \\
\hline \multirow{2}{*}{$\begin{array}{c}\text { Restatement } \\
\text { Variables }\end{array}$} & RESTATE_ALL & 0.21 & 0.19 & 0.03 & $* * *$ \\
\hline & RESTATE_BIGR & 0.10 & 0.07 & 0.04 & $* * *$ \\
\hline \multirow{4}{*}{$\begin{array}{l}\text { Proximity } \\
\text { Variables }\end{array}$} & PROXIMITY_TO_NATIONAL & -1.55 & -0.92 & -0.64 & $* * *$ \\
\hline & PROXIMITY_TO_LARGE & -0.26 & -0.21 & -0.05 & $* * *$ \\
\hline & PROXIMITY_TO_CLIENT & -0.13 & -0.11 & -0.02 & $* * *$ \\
\hline & PROXIMITY_TO_SEC & -0.19 & -0.15 & -0.04 & $* * *$ \\
\hline \multirow{17}{*}{$\begin{array}{c}\text { Client Firm } \\
\text { Variables }\end{array}$} & SIZE_CLIENT & 6.82 & 7.42 & -0.60 & $* * *$ \\
\hline & CASH_FLOWS & 0.06 & 0.08 & -0.02 & $* * *$ \\
\hline & LOSS & 0.29 & 0.22 & 0.06 & $* * *$ \\
\hline & $D E B T$ & 0.54 & 0.59 & -0.05 & $* * *$ \\
\hline & $R S S T \_A C C$ & 0.02 & 0.02 & 0.01 & $* * *$ \\
\hline & $C H G \_R E C$ & 0.01 & 0.01 & 0.00 & $*$ \\
\hline & CHG_INV & 0.15 & 0.10 & 0.04 & $* * *$ \\
\hline & CHG_CASH_SALE & 0.11 & 0.07 & 0.04 & $* * *$ \\
\hline & CHG_EARN & -0.14 & -0.18 & 0.04 & \\
\hline & ISSUE & 0.94 & 0.93 & 0.01 & $* * *$ \\
\hline & $C H G \_E M P$ & -0.05 & -0.04 & -0.01 & $* * *$ \\
\hline & $O P \_L E A S E S$ & 0.00 & 0.00 & 0.00 & $*$ \\
\hline & BTM & 0.59 & 0.59 & 0.00 & \\
\hline & ABNORMAL_RET & 0.08 & 0.05 & 0.04 & $* * *$ \\
\hline & TENURE & 5.59 & 6.95 & -1.35 & $* * *$ \\
\hline & AUDITOR_CHANGE & 0.05 & 0.04 & 0.01 & $* * *$ \\
\hline & $G C$ & 0.02 & 0.01 & 0.01 & $* * *$ \\
\hline \multirow{6}{*}{$\begin{array}{c}\text { Auditor } \\
\text { Variables }\end{array}$} & SIZE_AUDITOR & 16.93 & 17.74 & -0.81 & $* * *$ \\
\hline & $A U D I T$ & 13.75 & 14.21 & -0.46 & $* * *$ \\
\hline & NON_AUDIT & 11.44 & 11.73 & -0.29 & $* * *$ \\
\hline & INFLUENCE & 0.11 & 0.07 & 0.04 & $* * *$ \\
\hline & NATIONAL_LEADER & 0.32 & 0.33 & -0.01 & $* *$ \\
\hline & CITY_LEADER & 0.71 & 0.62 & 0.09 & $* * *$ \\
\hline \multirow{2}{*}{$\begin{array}{c}\text { City } \\
\text { Variables }\end{array}$} & POPULATION & 14.68 & 15.25 & -0.57 & $* * *$ \\
\hline & $G D P P C$ & 10.97 & 10.93 & 0.04 & $* * *$ \\
\hline
\end{tabular}

Notes: Table 2, Panel A presents the descriptive statistics for the firm-year variables based on the full sample $(\mathrm{n}=32,987)$. Panel B presents a comparison of mean values for the firm-year variables with (i.e., Treated) and without (i.e., Untreated) direct airline routes based on the sample for $\operatorname{DIRECT}(\mathrm{n}=25,299)$. ***, **, * indicate significance at the $0.01,0.05$, and 0.10 levels, respectively. All continuous variables are winsorized at the 1 percent and 99 percent levels. All variables are defined in Appendix A. 


\section{TABLE 3}

\section{National Office Governance and Audit Quality}

RESTATE $=\beta_{0}+\beta_{1}$ PROXIMITY $+\sum \beta_{i}$ Other Proximity Controls $+\sum \beta_{j}$ Client Firm Controls

$+\sum \beta_{k}$ Auditor Controls $+\sum \beta_{l}$ City Controls + Fixed Effects (Industry, Year, Audit firm) $+\varepsilon$

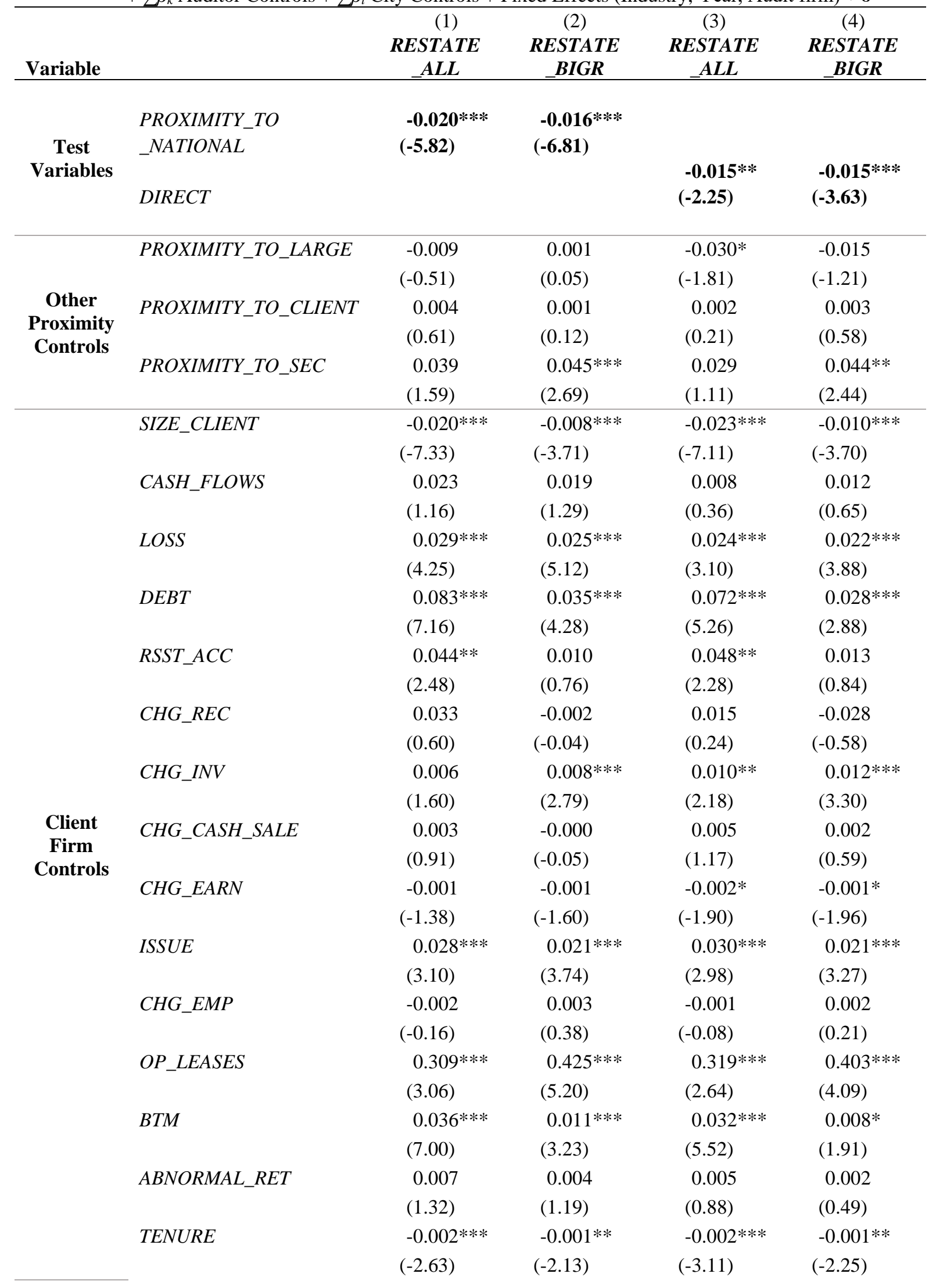




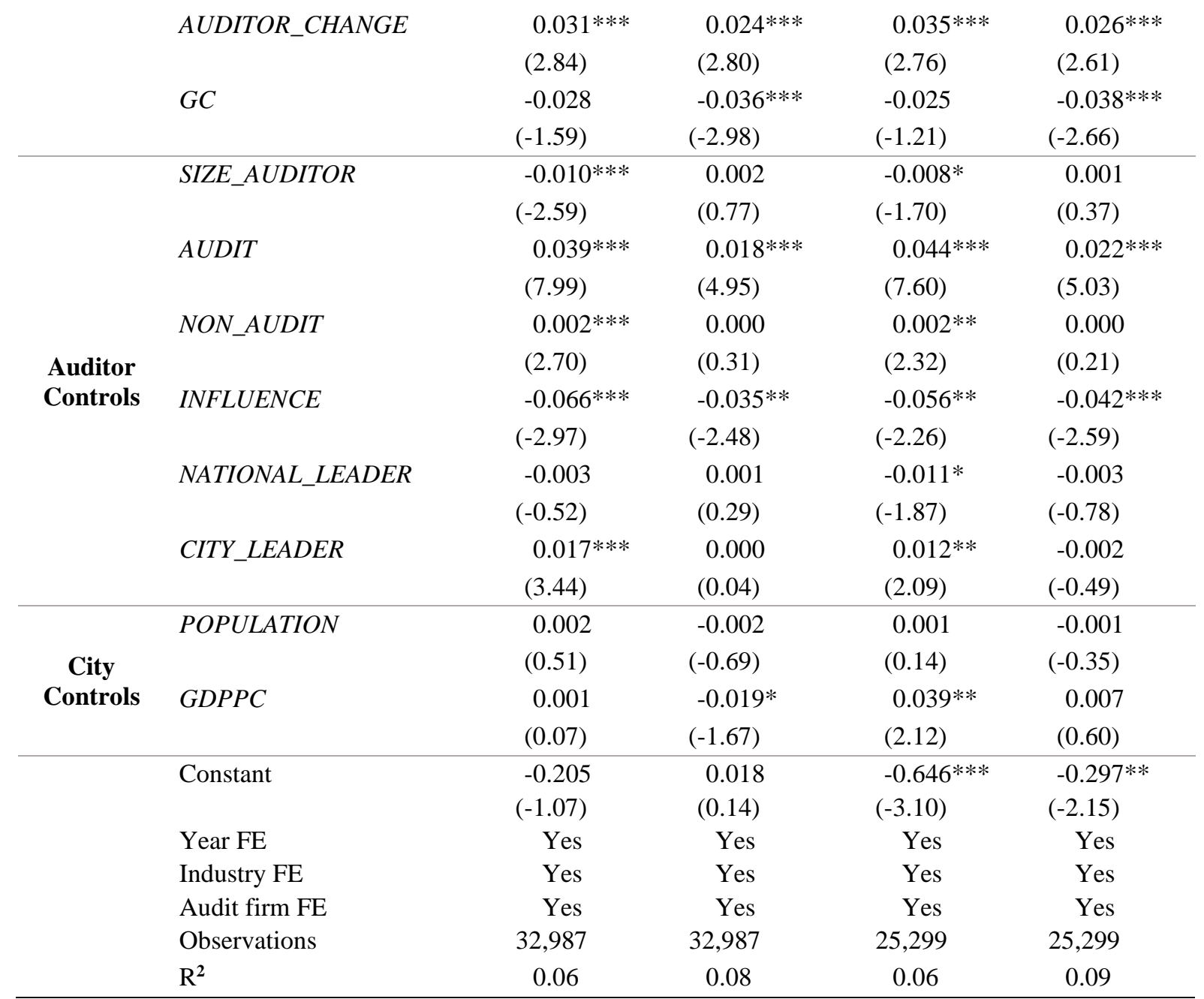

Notes: This table presents results of estimating OLS regression Eq. (1). The dependent variable in columns (1) and (3) is RESTATE_ALL, which is an indicator variable equals one if a client-year's $10-\mathrm{K}$ filing was restated subsequently (including both non-reliance restatements under Item 4.02 and other restatements), and zero otherwise. The dependent variable in columns (2) and (4) is RESTATE_BIGR, which is an indicator variable equals one if a client-year's 10-K filing was restated and an Item 4.02 non-reliance misstatement disclosure was issued in an 8-K filing, and zero otherwise. PROXIMITY is one of the two proxies we use to measure national office proximity, PROXIMITY TO NATIONAL and DIRECT. PROXIMITY_TO_NATIONAL is the total distance (in thousands of miles) between the opinion signing audit office and the national office of the firm multiplied by negative one. DIRECT is an indicator variable that equals one when a direct airline route with at least 100 flights per year between the opinion signing audit office and its national office has been introduced by time $t$, and zero otherwise. All other variables are defined in Appendix A. Year, industry (based on 2-digit SIC codes), and audit firm fixed effects are included in all models. Standard errors are clustered at the auditor-office-year level. t-statistics are reported in parentheses. ${ }^{* * *}, * *, *$ indicate significance at the $0.01,0.05$, and 0.10 levels, respectively, using two-tailed tests. All continuous variables are winsorized at the 1 percent and 99 percent levels. 


\begin{tabular}{|c|c|c|}
\hline \multicolumn{3}{|c|}{$\begin{aligned} & \text { Dynamic Effects of the Introduction of Direct Airline Routes } \\
& \text { RESTATE }= \beta_{0}+\beta_{1} \text { DIRECT_INTRO_PRIOR }+\beta_{2} \text { DIRECT_INTRO }+\beta_{3} \text { DIRECT_INTRO_POST } \\
&+\beta_{4} \text { DIRECT_CONT }+\sum \beta_{i} \text { Other Proximity Controls }+\sum \beta_{j} \text { Client Firm Controls } \\
&+\sum \beta_{k} \text { Auditor Controls }+\sum \beta_{l} \text { City Controls }+ \text { Fixed Effects (Industry, Year, Audit firm) }+\varepsilon\end{aligned}$} \\
\hline & $(1)$ & $(2)$ \\
\hline Variable & RESTATE_ALL & RESTATE_BIGR \\
\hline DIRECT_INTRO_PRIOR & $\begin{array}{l}0.001 \\
(0.09)\end{array}$ & $\begin{array}{l}0.015 \\
(1.57)\end{array}$ \\
\hline DIRECT_INTRO & $\begin{array}{l}-0.046 * * * \\
(-3.68)\end{array}$ & $\begin{array}{l}-0.018 * * \\
(-2.10)\end{array}$ \\
\hline$D I R E C T \_I N T R O \_P O S T$ & $\begin{array}{l}-0.036 * * * \\
(-2.98)\end{array}$ & $\begin{array}{l}-0.027 * * * \\
(-3.13)\end{array}$ \\
\hline DIRECT_CONT & $\begin{array}{l}-0.019 * * \\
(-2.45)\end{array}$ & $\begin{array}{l}-0.015^{* *} \\
(-2.46)\end{array}$ \\
\hline Controls & Yes & Yes \\
\hline Year FE & Yes & Yes \\
\hline Industry FE & Yes & Yes \\
\hline Audit firm FE & Yes & Yes \\
\hline Observations & 25,299 & 25,299 \\
\hline $\mathrm{R}^{2}$ & 0.07 & 0.09 \\
\hline \multicolumn{3}{|c|}{$\begin{array}{l}\text { Notes: This table presents the dynamics of the effects of the introduction of direct airline routes. The dependent variable in } \\
\text { columns (1) is } R E S T A T E \_A L L \text {, which is an indicator variable equals one if a client-year's } 10-\mathrm{K} \text { filing was restated subsequently } \\
\text { (including both non-reliance restatements under Item } 4.02 \text { and other restatements), and zero otherwise. The dependent variable } \\
\text { in columns (2) is RESTATE_BIGR, which is an indicator variable equals one if a client-year's } 10 \text {-K filing was restated and an } \\
\text { Item } 4.02 \text { non-reliance misstatement disclosure was issued in an } 8 \text {-K filing, and zero otherwise. DIRECT_INTRO_PRIOR is } \\
\text { an indicator variable that equals one if a direct airline route with at least } 100 \text { flights per year between the opinion signing audit } \\
\text { office and its national office is introduced in } \mathrm{t}+1 \text {, and zero otherwise. DIRECT_INTRO is an indicator variable that equals one } \\
\text { if a direct airline route with at least } 100 \text { flights per year between the opinion signing audit office and its national office is } \\
\text { introduced in t, and zero otherwise. DIRECT_INTRO_POST is an indicator variable that equals one if a direct airline route } \\
\text { with at least } 100 \text { flights per year between the opinion signing audit office and its national office is introduced in t-1, and zero } \\
\text { otherwise. DIRECT_CONT is an indicator variable that equals one if a direct airline route with at least } 100 \text { flights per year } \\
\text { between the opinion signing audit office and its national office has been introduced in t- } 2 \text { or before, and the direct flight has } \\
\text { not been terminated, and } 0 \text { otherwise. All other variables are defined in Appendix A. Year, industry (based on } 2 \text {-digit SIC } \\
\text { codes), and audit firm fixed effects are included in all models. Standard errors are clustered at the auditor-office-year level. t- } \\
\text { statistics are reported in parentheses. } * * *, * *, * \text { indicate significance at the } 0.01,0.05 \text {, and } 0.10 \text { levels, respectively, using two- } \\
\text { tailed tests. All continuous variables are winsorized at the } 1 \text { percent and } 99 \text { percent levels. }\end{array}$} \\
\hline
\end{tabular}




\begin{tabular}{|c|c|c|c|c|}
\hline \multicolumn{5}{|c|}{$\begin{aligned} \text { RESTATE }= & \beta_{0}+\beta_{1} \text { PROXIMITY }+\beta_{2} \text { SCANDAL }(\text { PARTI_INCREASE }) \\
& +\beta_{3} \text { PROXIMITY*SCANDAL }(\text { PARTI_INCREASE })+\sum \beta_{i} \text { Other Proximity Controls } \\
& +\sum \beta_{j} \text { Client Firm Controls }+\sum \beta_{k} \text { Auditor Controls }+\sum \beta_{l} \text { City Controls } \\
& + \text { Fixed Effects (Industry, Year, Audit firm })+\varepsilon\end{aligned}$} \\
\hline \multicolumn{5}{|c|}{ Panel A: National Office Time Constraints } \\
\hline Variable & $\begin{array}{l}(1) \\
\text { RESTATE } \\
\quad \text { ALL } \\
\end{array}$ & $\begin{array}{l}(2) \\
\text { RESTATE } \\
\text { BIGR } \\
\end{array}$ & $\begin{array}{l}(3) \\
\text { RESTATE } \\
\quad \text { ALL } \\
\end{array}$ & $\begin{array}{l}\text { (4) } \\
\text { RESTATE } \\
\text { BIGR } \\
\end{array}$ \\
\hline PROXIMITY_TO_NATIONAL & $\begin{array}{l}-0.016^{* * * *} \\
(-4.04)\end{array}$ & $\begin{array}{l}-0.013 * * * \\
(-5.37)\end{array}$ & & \\
\hline DIRECT & & & $\begin{array}{l}-0.005 \\
(-0.62)\end{array}$ & $\begin{array}{l}-0.008^{*} \\
(-1.78)\end{array}$ \\
\hline$S C A N D A L$ & $\begin{array}{l}-0.005 \\
(-0.55)\end{array}$ & $\begin{array}{l}0.020^{* * * *} \\
(3.02)\end{array}$ & $\begin{array}{l}0.015^{*} \\
(1.68)\end{array}$ & $\begin{array}{l}0.033^{* * *} \\
(5.15)\end{array}$ \\
\hline $\begin{array}{l}\text { PROXIMITY_TO_NATIONAL } \\
\text { * SCANDAL }\end{array}$ & $\begin{array}{l}-0.010^{*} \\
(-1.65)\end{array}$ & $\begin{array}{l}-0.007 \\
(-1.64)\end{array}$ & & \\
\hline$D I R E C T * S C A N D A L$ & & & $\begin{array}{l}-0.030 * * \\
(-2.44)\end{array}$ & $\begin{array}{l}-0.021 * * \\
(-2.50)\end{array}$ \\
\hline Controls & Yes & Yes & Yes & Yes \\
\hline Year FE & Yes & Yes & Yes & Yes \\
\hline Industry FE & Yes & Yes & Yes & Yes \\
\hline Audit firm FE & Yes & Yes & Yes & Yes \\
\hline Observations & 32,987 & 32,987 & 25,299 & 25,299 \\
\hline $\mathrm{R}^{2}$ & 0.06 & 0.09 & 0.07 & 0.09 \\
\hline Panel B: Increased Audit Def & ates & & & \\
\hline Variable & $\begin{array}{l}(1) \\
\text { RESTATE } \\
\quad \text { ALL } \\
\end{array}$ & $\begin{array}{l}(2) \\
\text { RESTATE } \\
\quad \text { BIGR } \\
\end{array}$ & $\begin{array}{l}(3) \\
\text { RESTATE } \\
\quad \text { ALL } \\
\end{array}$ & $\begin{array}{c}(4) \\
\text { RESTATE } \\
\text { BIGR }\end{array}$ \\
\hline PROXIMITY_TO_NATIONAL & $\begin{array}{l}-0.023 * * * \\
(-6.21)\end{array}$ & $\begin{array}{l}-0.018 * * * \\
(-6.83)\end{array}$ & & \\
\hline DIRECT & & & $\begin{array}{l}-0.025^{* * * *} \\
(-3.42)\end{array}$ & $\begin{array}{l}-0.022 * * * \\
(-4.34)\end{array}$ \\
\hline PARTI_INCREASE & $\begin{array}{l}0.031 * * \\
(2.55)\end{array}$ & $\begin{array}{c}0.004 \\
(0.87)\end{array}$ & $\begin{array}{l}-0.009 \\
(-0.77)\end{array}$ & $\begin{array}{l}-0.020 * * * \\
(-3.72)\end{array}$ \\
\hline $\begin{array}{l}\text { PROXIMITY_TO_NATIONAL } \\
\text { * PARTI_INCREASE }\end{array}$ & $\begin{array}{l}0.018 * * \\
(2.38)\end{array}$ & $\begin{array}{l}0.011 * * * \\
(3.23)\end{array}$ & & \\
\hline DIRECT*PARTI_INCREASE & & & $\begin{array}{l}0.046 * * * \\
(3.26)\end{array}$ & $\begin{array}{l}0.029 * * * \\
(4.27)\end{array}$ \\
\hline Controls & Yes & Yes & Yes & Yes \\
\hline Year FE & Yes & Yes & Yes & Yes \\
\hline Industry FE & Yes & Yes & Yes & Yes \\
\hline Audit firm FE & Yes & Yes & Yes & Yes \\
\hline Observations & 32,987 & 32,987 & 25,299 & 25,299 \\
\hline $\mathrm{R}^{2}$ & 0.06 & 0.08 & 0.07 & 0.09 \\
\hline
\end{tabular}


Notes: This table presents cross-sectional results by estimating OLS regression Eq. (1) and adding SCANDAL (PARTI INCREASE) and an interaction term, PROXIMITY* SCANDAL (PARTI_INCREASE) in Panel A (Panel B). PROXIMITY is one of the two proxies we use to measure national office proximity, PROXIMITY_TO_NATIONAL and DIRECT. SCANDAL is an indicator variable that equals one if the audit firm is in the year of the revelation of major audit scandal(s) and the two years after, and zero otherwise. PARTI_INCREASE is an indicator variable that equals one if the ratio of total part I findings to total engagements reviewed by PCAOB of an audit firm increases by over 10 percent from t-1 to t, and zero otherwise. All other variables are defined in Appendix A. Year, industry (based on 2-digit SIC codes), and audit firm fixed effects are included in all models. Standard errors are clustered at the auditor-office-year level. t-statistics are reported in parentheses. $* * *, * *, *$ indicate significance at the $0.01,0.05$, and 0.10 levels, respectively, using two-tailed tests. All continuous variables are winsorized the 1 percent and 99 percent levels. 


\begin{tabular}{|c|c|c|c|c|}
\hline \multicolumn{5}{|c|}{$\begin{aligned} & \text { TABLE } 6 \\
& \text { Channels of National Office Governance } \\
& \text { RESTATE }= \beta_{0}+\beta_{1} \text { PROXIMITY }+\beta_{2} P C A O B\left(R E M O T E \text { or } L A R G E \_O F F I C E\right) \\
&+\beta_{3} P R O X I M I T Y^{*} P C A O B\left(R E M O T E \text { or } L A R G E \_O F F I C E\right)+\sum \beta_{i} \text { Other Proximity Controls } \\
&+\sum \beta_{j} \text { Client Firm Controls }+\sum \beta_{k} \text { Auditor Controls }+\sum \beta_{l} \text { City Controls } \\
&+ \text { Fixed Effects (Industry, Year, Audit firm) }+\varepsilon\end{aligned}$} \\
\hline \multicolumn{5}{|c|}{ Panel A: PCAOB Inspection } \\
\hline Variable & $\begin{array}{c}(1) \\
\text { RESTATE } \\
\text { ALL } \\
\end{array}$ & $\begin{array}{c}(2) \\
\text { RESTATE } \\
\text { BIGR } \\
\end{array}$ & $\begin{array}{c}(3) \\
\text { RESTATE } \\
\quad \text { ALL }\end{array}$ & $\begin{array}{c}(4) \\
\text { RESTATE } \\
\text { _BIGR }\end{array}$ \\
\hline PROXIMITY_TO_NATIONAL & $\begin{array}{l}-0.025 * * * \\
(-3.67)\end{array}$ & $\begin{array}{l}-0.022 * * * \\
(-4.03)\end{array}$ & & \\
\hline DIRECT & & & $\begin{array}{l}-0.043 * * * \\
(-2.90)\end{array}$ & $\begin{array}{l}-0.049 * * * \\
(-3.99)\end{array}$ \\
\hline РСАОВ & $\begin{array}{l}-0.082 * * * \\
(-6.42)\end{array}$ & $\begin{array}{l}-0.106^{* * * *} \\
(-11.64)\end{array}$ & $\begin{array}{l}-0.097 * * * \\
(-7.82)\end{array}$ & $\begin{array}{l}-0.129 * * * \\
(-13.88)\end{array}$ \\
\hline $\begin{array}{l}\text { PROXIMITY_TO_NATIONAL } \\
* \text { PCAOB }\end{array}$ & $\begin{array}{c}0.005 \\
(\mathbf{0 . 7 3})\end{array}$ & $\begin{array}{l}0.011 * * \\
(1.96)\end{array}$ & & \\
\hline$D I R E C T^{*} P C A O B$ & & & $\begin{array}{r}\mathbf{0 . 0 2 2} \\
(\mathbf{1 . 3 8})\end{array}$ & $\begin{array}{l}\mathbf{0 . 0 3 3}^{* * *} \\
(\mathbf{2 . 6 6 )}\end{array}$ \\
\hline Controls & Yes & Yes & Yes & Yes \\
\hline Year FE & No & No & No & No \\
\hline Industry FE & Yes & Yes & Yes & Yes \\
\hline Audit firm FE & Yes & Yes & Yes & Yes \\
\hline Observations & 28,586 & 28,586 & 21,982 & 21,982 \\
\hline $\mathrm{R}^{2}$ & 0.05 & 0.06 & 0.05 & 0.06 \\
\hline Panel B: Remote to Large Off & $\begin{array}{c}(1) \\
\text { RESTATE } \\
\quad \text { ALL } \\
\end{array}$ & $\begin{array}{c}(2) \\
\text { RESTATE } \\
\text { BIGR }\end{array}$ & $\begin{array}{c}(3) \\
\text { RESTATE } \\
\quad \text { ALL }\end{array}$ & $\begin{array}{c}(4) \\
\text { RESTATE } \\
\text { _BIGR } \\
\end{array}$ \\
\hline PROXIMITY_TO_NATIONAL & $\begin{array}{l}-0.018 * * * \\
(-4.79)\end{array}$ & $\begin{array}{l}-0.017 * * * \\
(-6.49)\end{array}$ & & \\
\hline DIRECT & & & $\begin{array}{l}-0.007 \\
(-0.88)\end{array}$ & $\begin{array}{l}-0.009^{*} \\
(-1.72)\end{array}$ \\
\hline REMOTE & $\begin{array}{l}-0.035^{* *} \\
(-2.34)\end{array}$ & $\begin{array}{l}-0.024 * * \\
(-2.51)\end{array}$ & $\begin{array}{c}0.003 \\
(0.29)\end{array}$ & $\begin{array}{l}-0.008 \\
(-1.07)\end{array}$ \\
\hline $\begin{array}{l}\text { PROXIMITY_TO_NATIONAL } \\
* \text { REMOTE }\end{array}$ & $\begin{array}{l}-0.013 * \\
(-1.67)\end{array}$ & $\begin{array}{l}-0.000 \\
(-0.07)\end{array}$ & & \\
\hline DIRECT*REMOTE & & & $\begin{array}{l}-0.024 * \\
(-1.82)\end{array}$ & $\begin{array}{l}-0.020^{* *} \\
(-2.37)\end{array}$ \\
\hline Controls & Yes & Yes & Yes & Yes \\
\hline Year FE & Yes & Yes & Yes & Yes \\
\hline Industry FE & Yes & Yes & Yes & Yes \\
\hline Audit firm FE & Yes & Yes & Yes & Yes \\
\hline Observations & 32,987 & 32,987 & 25,299 & 25,299 \\
\hline $\mathrm{R}^{2}$ & 0.06 & 0.08 & 0.07 & 0.09 \\
\hline
\end{tabular}


TABLE 6 (continued)

Panel C: Large Offices

\begin{tabular}{|c|c|c|c|c|}
\hline Variable & $\begin{array}{c}(1) \\
\text { RESTATE } \\
\quad A L L\end{array}$ & $\begin{array}{c}(2) \\
\text { RESTATE } \\
\text { BIGR }\end{array}$ & $\begin{array}{c}(3) \\
\text { RESTATE } \\
\quad \text { ALL }\end{array}$ & $\begin{array}{c}(4) \\
\text { RESTATI } \\
\text { BIGR }\end{array}$ \\
\hline PROXIMITY_TO_NATIONAL & $\begin{array}{l}-0.022 * * * \\
(-5.70)\end{array}$ & $\begin{array}{l}-0.018 * * * \\
(-6.76)\end{array}$ & & \\
\hline DIRECT & & & $\begin{array}{l}-0.020 * * * \\
(-2.79)\end{array}$ & $\begin{array}{l}-0.020 * * * \\
(-4.53)\end{array}$ \\
\hline LARGE_OFFICE & $\begin{array}{r}0.001 \\
(0.09)\end{array}$ & $\begin{array}{c}0.004 \\
(0.60)\end{array}$ & $\begin{array}{l}-0.033 * * \\
(-2.43)\end{array}$ & $\begin{array}{l}-0.023 * * * \\
(-2.65)\end{array}$ \\
\hline $\begin{array}{l}\text { PROXIMITY_TO_NATIONAL } \\
* \text { LARGE_OFFICE }\end{array}$ & $\begin{array}{r}0.010 \\
(1.27)\end{array}$ & $\begin{array}{l}0.009 * \\
(1.82)\end{array}$ & & \\
\hline DIRECT*LARGE_OFFICE & & & $\begin{array}{l}0.035 * * \\
(2.24)\end{array}$ & $\begin{array}{l}\text { 0.032**** } \\
(\mathbf{3 . 3 1})\end{array}$ \\
\hline Controls & Yes & Yes & Yes & Yes \\
\hline Year FE & Yes & Yes & Yes & Yes \\
\hline Industry FE & Yes & Yes & Yes & Yes \\
\hline Audit firm FE & Yes & Yes & Yes & Yes \\
\hline Observations & 32,987 & 32,987 & 25,299 & 25,299 \\
\hline $\mathrm{R}^{2}$ & 0.06 & 0.08 & 0.07 & 0.09 \\
\hline
\end{tabular}

Notes: This table presents time-series (cross-sectional) results by estimating OLS regression Eq. (1) and adding PCAOB (REMOTE or LARGE_OFFICE) and an interaction term, PROXIMITY * PCAOB (REMOTE or LARGE_OFFICE) in Panel A (Panel B or Panel C). PROXIMITY is one of the two proxies we use to measure national office proximity, PROXIMITY TO_NATIONAL and DIRECT. $P C A O B$ is an indicator variable that equals one for fiscal years beginning 2006 and onward, and zero for fiscal years before 2004. REMOTE is an indicator variable that equals one if the local office's proximity to the closest large office is in the lowest quartile (i.e., the farthest away from a within-firm large office), and zero otherwise. LARGE_OFFICE is an indicator variable that equals one if the SIZE_AUDITOR of the opinion signing audit office is in the highest quartile of the sample, and zero otherwise. All other variables are defined in Appendix A. As we are exploring the time-series variation, we exclude year fixed effects from the model in Panel A. Industry (based on 2-digit SIC codes) and audit firm fixed effects are included in all specifications in Panel A. Year, industry (based on 2-digit SIC codes), and audit firm fixed effects are included in all specifications in Panel B and Panel C. Standard errors are clustered at the auditor-office-year level. $\mathrm{t}$-statistics are reported in parentheses. ***, **,* indicate significance at the $0.01,0.05$, and 0.10 levels, respectively, using two-tailed tests. All continuous variables are winsorized at the 1 percent and 99 percent levels. 
TABLE 7

Small Audit Firms

Panel A: Comparison of Mean between Small Firms and Big 4 Firms

\begin{tabular}{|c|c|c|c|c|c|}
\hline \multirow[t]{3}{*}{ Variable } & & $\begin{array}{r}\text { Mean_Small } \\
\text { Firms } \\
\end{array}$ & Mean_Big4 & \multicolumn{2}{|c|}{$\begin{array}{c}\text { Mean_Difference } \\
\text { (Small firms - Big4) }\end{array}$} \\
\hline & $\mathrm{N}$ & 4,241 & 32,987 & & \\
\hline & Number of offices & 22 & 70 & & \\
\hline \multirow{2}{*}{$\begin{array}{l}\text { Restatement } \\
\text { Variables }\end{array}$} & RESTATE_ALL & 0.17 & 0.20 & -0.04 & $* * *$ \\
\hline & RESTATE_BIGR & 0.09 & 0.09 & 0.00 & \\
\hline \multirow{3}{*}{$\begin{array}{l}\text { Proximity } \\
\text { Variables }\end{array}$} & PROXIMITY_TO_NATIONAL & -0.75 & -1.05 & 0.30 & $* * *$ \\
\hline & PROXIMITY_TO_LARGE & -0.34 & -0.19 & -0.15 & $* * *$ \\
\hline & PROXIMITY_TO_CLIENT & -0.16 & -0.12 & -0.04 & $* * *$ \\
\hline \multirow{6}{*}{$\begin{array}{l}\text { Auditor } \\
\text { Variables }\end{array}$} & SIZE_AUDITOR & 15.17 & 17.42 & -2.25 & $* * *$ \\
\hline & AUDIT & 12.80 & 13.94 & -1.15 & $* * *$ \\
\hline & NON_AUDIT & 8.91 & 11.67 & -2.76 & $* * *$ \\
\hline & INFLUENCE & 0.17 & 0.09 & 0.09 & $* * *$ \\
\hline & NATIONAL_LEADER & 0.00 & 0.33 & -0.33 & $* * *$ \\
\hline & CITY_LEADER & 0.39 & 0.66 & -0.27 & $* * *$ \\
\hline
\end{tabular}

Panel B: Comparison of Standard Deviation between Small Firms and Big 4 Firms

\begin{tabular}{|c|c|c|c|c|c|}
\hline \multicolumn{2}{|l|}{ Variable } & \multirow{2}{*}{$\begin{array}{r}\begin{array}{r}\text { Std_Small } \\
\text { Firms }\end{array} \\
0.37\end{array}$} & \multirow{2}{*}{$\begin{array}{r}\text { Std_Big4 } \\
0.40\end{array}$} & \multicolumn{2}{|c|}{$\begin{array}{c}\text { Std_Difference } \\
\text { (Small firms - Big4) }\end{array}$} \\
\hline Restatement & RESTATE_ALL & & & -0.03 & $* * *$ \\
\hline Variables & RESTATE_BIGR & 0.28 & 0.28 & 0.00 & \\
\hline \multirow{3}{*}{$\begin{array}{l}\text { Proximity } \\
\text { Variables }\end{array}$} & PROXIMITY_TO_NATIONAL & 0.63 & 0.88 & -0.25 & $* * *$ \\
\hline & PROXIMITY_TO_LARGE & 0.40 & 0.23 & 0.18 & $* * *$ \\
\hline & PROXIMITY_TO_CLIENT & 0.39 & 0.36 & 0.03 & $* * *$ \\
\hline \multirow{6}{*}{$\begin{array}{c}\text { Auditor } \\
\text { Variables }\end{array}$} & SIZE_AUDITOR & 1.19 & 1.39 & -0.19 & $* * *$ \\
\hline & AUDIT & 0.99 & 1.24 & -0.25 & $* * *$ \\
\hline & NON_AUDIT & 4.37 & 3.27 & 1.10 & $* * *$ \\
\hline & INFLUENCE & 0.22 & 0.16 & 0.07 & $* * *$ \\
\hline & NATIONAL_LEADER & 0.04 & 0.47 & -0.43 & $* * *$ \\
\hline & CITY_LEADER & 0.49 & 0.47 & 0.01 & $* * *$ \\
\hline
\end{tabular}




\section{TABLE 7 (continued)}

\begin{tabular}{|c|c|c|c|c|}
\hline \multicolumn{5}{|c|}{$\begin{array}{l}\text { Panel C: Multivariate Regression } \\
\begin{aligned} \text { RESTATE }= & \beta_{0}+\beta_{1} P R O X I M I T Y+\beta_{2} S M A L L_{-} F I R M+\beta_{3} P R O X I M I T Y^{*} S M A L L \_F I R M \\
& +\sum \beta_{i} \text { Other Proximity Controls }+\sum \beta_{j} \text { Client Firm Controls }+\sum \beta_{k} \text { Auditor Controls } \\
& +\sum \beta_{l} \text { City Controls + Fixed Effects (Industry, Year, Audit firm) }+\varepsilon\end{aligned}\end{array}$} \\
\hline Variable & $\begin{array}{l}\text { (1) } \\
\text { RESTATE } \\
\quad \text { ALL } \\
\end{array}$ & $\begin{array}{l}\text { (2) } \\
\text { RESTATE } \\
\text { BIGR } \\
\end{array}$ & $\begin{array}{l}\text { (3) } \\
\text { RESTATE } \\
\quad \text { ALL }\end{array}$ & $\begin{array}{l}\text { (4) } \\
\text { RESTATE } \\
\quad \text { BIGR } \\
\end{array}$ \\
\hline PROXIMITY_TO_NATIONAL & $\begin{array}{l}-0.019 * * * \\
(-5.71)\end{array}$ & $\begin{array}{l}-0.016^{* * * *} \\
(-6.82)\end{array}$ & & \\
\hline DIRECT & & & $\begin{array}{l}-0.010 \\
(-1.51)\end{array}$ & $\begin{array}{l}-0.015^{* * *} \\
(-3.60)\end{array}$ \\
\hline SMALL_FIRM & $\begin{array}{l}-0.158^{* * * *} \\
(-6.11)\end{array}$ & $\begin{array}{r}0.017 \\
(0.75)\end{array}$ & $\begin{array}{l}-0.205^{* * *} \\
(-7.98)\end{array}$ & $\begin{array}{l}-0.092 * * * \\
(-3.60)\end{array}$ \\
\hline $\begin{array}{l}\text { PROXIMITY_TO_NATIONAL } \\
\text { * SMALL_FIRM }\end{array}$ & $\begin{array}{c}0.015 \\
(\mathbf{1 . 4 2})\end{array}$ & $\begin{array}{l}0.020 * * * \\
(2.62)\end{array}$ & & \\
\hline$D I R E C T^{*} S M A L L \_F I R M$ & & & $\begin{array}{l}0.031 * \\
(1.89)\end{array}$ & $\begin{array}{l}\mathbf{0 . 0 3 2} * * * \\
(\mathbf{2 . 8 5})\end{array}$ \\
\hline Controls & Yes & Yes & Yes & Yes \\
\hline Year FE & Yes & Yes & Yes & Yes \\
\hline Industry FE & Yes & Yes & Yes & Yes \\
\hline Audit firm FE & No & No & No & No \\
\hline Observations & 37,228 & 37,228 & 28,710 & 28,710 \\
\hline $\mathrm{R}^{2}$ & 0.06 & 0.08 & 0.06 & 0.08 \\
\hline
\end{tabular}

Notes: This table presents univariate and multivariate tests based on a sample of firm-year observations of the nine audit firms (Big 4 and five lower-tier firms, i.e., Grant Thornton, BDO Seidman, Crowe Chizek, Plante \& Moran, and McGladrey \& Pullen) from 2000 through 2017 available in the Compustat-Audit Analytics merged sample $(\mathrm{n}=37,228)$. Panel A (Panel B) presents the comparison of mean values (standard deviations) for the firm-year variables in the five smaller audit firms and Big 4 audit firms. Panel C presents cross-sectional results by estimating OLS regression Eq. (1) and adding SMALL_FIRM and an interaction term, PROXIMITY * SMALL_FIRM. PROXIMITY is one of the two proxies we use to measure national office proximity, PROXIMITY_TO_NATIONAL and DIRECT. SMALL_FIRM is an indicator variable that equals one if the audit firm is one of the five smaller audit firms, and zero if the audit firm is one of the Big 4 firms. When using DIRECT in columns (3) and (4), we eliminate observations have local offices located within 200 miles from the national office $(\mathrm{n}=28,710)$. All other variables are defined in Appendix A. Year, industry (based on 2-digit SIC codes), and audit firm fixed effects are included in all specifications. Standard errors are clustered at the auditor-office-year level. t-statistics are reported in parentheses. ***, **, * indicate significance at the $0.01,0.05$, and 0.10 levels, respectively, using two-tailed tests. All continuous variables are winsorized at the 1 percent and 99 percent levels. 
TABLE 8

Local Shocks and the Introduction of Direct Airline Routes

RESTATE $=\beta_{0}+\beta_{1}$ DIRECT $+\sum \beta_{i}$ Other Proximity Controls $+\sum \beta_{j}$ Client Firm Controls $+\sum \beta_{k}$ Auditor Controls

$+\sum \beta_{l}$ City Controls $+\beta_{m}$ MSA-Year Control + Fixed Effects (Industry, Year, Audit firm) $+\varepsilon$

(1)

(2)

Variable

RESTATE_ALL

RESTATE_BIGR

Test Variable DIRECT

PROXIMITY_TO_LARGE

\begin{tabular}{|c|c|c|c|}
\hline \multirow{6}{*}{$\begin{array}{l}\text { Other } \\
\text { Proximity } \\
\text { Controls }\end{array}$} & \multirow{4}{*}{$\begin{array}{l}\text { PROXIMITY_TO_LARGE } \\
\text { PROXIMITY_TO_CLIENT }\end{array}$} & -0.023 & -0.007 \\
\hline & & $(-1.32)$ & $(-0.54)$ \\
\hline & & 0.000 & 0.001 \\
\hline & & $(0.05)$ & $(0.21)$ \\
\hline & \multirow[t]{2}{*}{ PROXIMITY_TO_SEC } & 0.023 & $0.033 *$ \\
\hline & & $(0.85)$ & $(1.82)$ \\
\hline & \multirow[t]{2}{*}{ SIZE_CLIENT } & $-0.024 * * *$ & $-0.010 * * *$ \\
\hline & & $(-7.12)$ & $(-3.73)$ \\
\hline & \multirow[t]{2}{*}{ CASH_FLOWS } & 0.009 & 0.014 \\
\hline & & $(0.37)$ & $(0.78)$ \\
\hline & \multirow[t]{2}{*}{$L O S S$} & $0.022 * * *$ & $0.021 * * *$ \\
\hline & & $(2.85)$ & $(3.78)$ \\
\hline & \multirow[t]{2}{*}{$D E B T$} & $0.074 * * *$ & $0.030 * * *$ \\
\hline & & $(5.30)$ & $(3.03)$ \\
\hline & \multirow[t]{2}{*}{$R S S T \_A C C$} & $0.043 * *$ & 0.014 \\
\hline & & $(2.03)$ & $(0.85)$ \\
\hline & \multirow[t]{2}{*}{$C H G \_R E C$} & 0.031 & -0.023 \\
\hline & & $(0.48)$ & $(-0.47)$ \\
\hline & \multirow[t]{2}{*}{$C H G \_I N V$} & $0.009 * *$ & $0.011 * * *$ \\
\hline \multirow{15}{*}{$\begin{array}{l}\text { Client Firm } \\
\text { Controls }\end{array}$} & & $(2.04)$ & $(3.16)$ \\
\hline & \multirow[t]{2}{*}{ CHG_CASH_SALE } & 0.005 & 0.002 \\
\hline & & $(1.23)$ & $(0.75)$ \\
\hline & \multirow[t]{2}{*}{ CHG_EARN } & $-0.001 *$ & $-0.001 *$ \\
\hline & & $(-1.82)$ & $(-1.89)$ \\
\hline & \multirow[t]{2}{*}{ ISSUE } & $0.033 * * *$ & $0.022 * * *$ \\
\hline & & (3.19) & $(3.36)$ \\
\hline & \multirow[t]{2}{*}{$C H G_{-} E M P$} & -0.003 & 0.002 \\
\hline & & $(-0.26)$ & $(0.18)$ \\
\hline & \multirow[t]{2}{*}{$O P_{-} L E A S E S$} & $0.327 * * *$ & $0.417 * * *$ \\
\hline & & $(2.64)$ & $(4.15)$ \\
\hline & \multirow[t]{2}{*}{$B T M$} & $0.035 * * *$ & $0.008 * *$ \\
\hline & & $(5.83)$ & (1.97) \\
\hline & \multirow[t]{2}{*}{$A B N O R M A L \_R E T$} & 0.004 & 0.001 \\
\hline & & $(0.65)$ & $(0.15)$ \\
\hline
\end{tabular}


TENURE

$-0.002 * * *$

$-0.001 * *$

AUDITOR_CHANGE

$(-3.05)$

$(-2.09)$

$0.038 * * *$

$0.028 * * *$

(2.96)

(2.78)

GC

$-0.024$

$-0.037 * *$

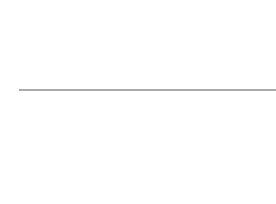

SIZE_AUDITOR

$(-1.15)$

$(-2.57)$

$-0.010^{* * *}$

0.001

AUDIT

$(-2.10)$

$(0.44)$

$0.046 * * *$

$0.022 * * *$

(7.88)

(4.87)

NON_AUDIT

$0.002 * *$

0.000

Auditor

Controls

INFLUENCE

$(0.51)$

$-0.084 * * *$

$-0.036^{* *}$

$(-3.17)$

$(-2.00)$

NATIONAL_LEADER

$-0.008$

$-0.003$

$(-1.42)$

$(-0.71)$

$0.011^{*}$

$-0.003$

CITY_LEADER

$(1.94)$

$(-0.60)$

POPULATION

0.003

$-0.002$

\begin{tabular}{clcc}
\hline & POPULATION & 0.003 & -0.002 \\
City Controls & & $(0.60)$ & $(-0.46)$ \\
& GDPPC & $0.036^{*}$ & -0.001 \\
& & $(1.87)$ & $(-0.07)$ \\
\hline & MSA-Year & $0.063^{*}$ & $0.120^{* *}$ \\
& Constant & $(1.73)$ & $(2.52)$ \\
& Year FE & $-0.629^{* * *}$ & -0.206 \\
Industry FE & $(-2.91)$ & $(-1.45)$ \\
Audit firm FE & Yes & Yes \\
& Observations & Yes & Yes \\
$\mathrm{R}^{2}$ & Yes & Yes \\
\hline
\end{tabular}

Notes: This table presents results of estimating OLS regression Eq. (1) by adding an MSA-Year control variable. The test variable is DIRECT, which is an indicator variable that equals one when a direct airline route with at least 100 flights per year between the opinion signing audit office and its national office has been introduced by time $t$, and zero otherwise. MSA-Year control is computed as the mean of the dependent variable (RESTATE_ALL and RESTATE_BIGR, respectively) in the audit office's MSA in a given year, excluding the office of interest. All other variables are defined in Appendix A. Year, industry (based on 2-digit SIC codes), and audit firm fixed effects are included in all models. Standard errors are clustered at the auditor-office-year level. t-statistics are reported in parentheses. $* * *, * *, *$ indicate significance at the $0.01,0.05$, and 0.10 levels, respectively, using two-tailed tests. All continuous variables are winsorized at the 1 percent and 99 percent levels. 
TABLE 9

Airline Price as an Alternative Measure of National Office Governance RESTATE $=\beta_{0}+\beta_{1}$ PRICE $+\sum \beta_{i}$ Other Proximity Controls $+\sum \beta_{j}$ Client Firm Controls $+\sum \beta_{k}$ Auditor Controls $+\sum \beta_{l}$ City Controls + Fixed Effects (Industry, Year, Audit firm) $+\varepsilon$

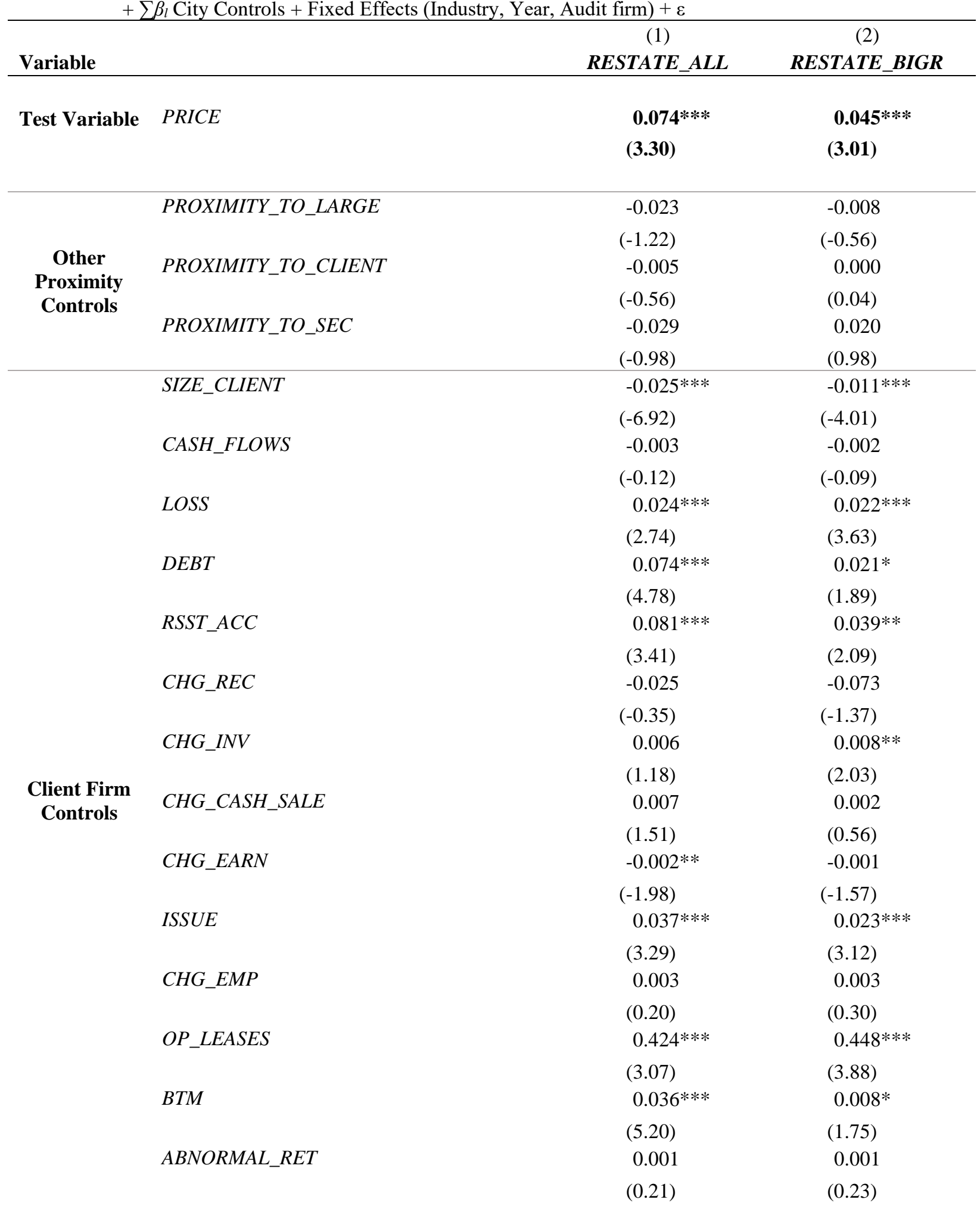


TENURE $\quad-0.001 \quad-0.001$

AUDITOR_CHANGE $\quad(-1.63) \quad(-1.32)$

(2.31) (2.16)

$G C-0.043 * \quad-0.050 * * *$

$(-1.80) \quad(-2.97)$

SIZE_AUDITOR $\quad-0.000 \quad-0.002$

AUDIT $0.042 * * * \quad 0.022 * * *$

NON_AUDIT $\quad 0.003 * * * \quad 0.001$

Auditor

Controls INFLUENCE

(3.09)

(1.53)

$-0.031-0.049 * * *$

$(-1.06) \quad(-2.64)$

NATIONAL_LEADER $\quad-0.011 * \quad-0.004$

$(-1.70) \quad(-0.89)$

CITY_LEADER $\quad 0.005 \quad-0.003$

\begin{tabular}{|c|c|c|c|}
\hline & & $(0.73)$ & $(-0.69)$ \\
\hline \multirow{4}{*}{ City Controls } & POPULATION & $-0.014 * *$ & -0.004 \\
\hline & \multirow{3}{*}{$G D P P C$} & $(-2.19)$ & $(-0.80)$ \\
\hline & & 0.007 & 0.002 \\
\hline & & $(0.31)$ & $(0.15)$ \\
\hline & \multirow[t]{2}{*}{ Constant } & -0.206 & -0.166 \\
\hline & & $(-0.76)$ & $(-1.00)$ \\
\hline & Year FE & Yes & Yes \\
\hline & Industry FE & Yes & Yes \\
\hline & Audit firm FE & Yes & Yes \\
\hline & Observations & 20,781 & 20,781 \\
\hline & $\mathrm{R}^{2}$ & 0.07 & 0.09 \\
\hline
\end{tabular}

Notes: This table presents results of estimating OLS regression Eq. (1) by using an alternative measure of national office governance. The test variable is PRICE, which is the annual average ticket price between two locations estimated using airline price data from the US Department of Transportation Airline Origin and Destination Survey (DB1B). All other variables are defined in Appendix A. Year, industry (based on 2-digit SIC codes), and audit firm fixed effects are included in all models. Standard errors are clustered at the auditor-office-year level. t-statistics are reported in parentheses. $* * *, * * *$ indicate significance at the $0.01,0.05$, and 0.10 levels, respectively, using two-tailed tests. All continuous variables are winsorized at the 1 percent and 99 percent levels. 